\title{
Artes plásticas y mujeres en la última dictadura argentina: análisis desde un caso trans-local*
}

\author{
PLASTIC ARTS AND WOMEN IN THE LAST ARGENTINE DICTATORSHIP: \\ ANALYSIS FROM A LOCAL (TRANS)CASE
}

ARTES PLÁSTICAS E MULHERES NA ÚLTIMA DITADURA ARGENTINA: ANÁLISE DESDE UM CASO TRANS-LOCAL

\section{Alejandra Soledad González**}

Cuadernos de Música, Artes Visuales y Artes Escénicas

/Volumen 13 - Número 1 / Enero - Junio de 2018

/ ISSN 1794-6670/ Bogotá, D.C., Colombia / pp. 13-42

Fecha de recepción: 30 de junio de 2017

Fecha de aceptación: 17 de septiembre de 2017

Disponible en línea: 6 de diciembre de 2017

doi:10.11144/javeriana.mavae13-1.apmu

* Artículo de investigación. Se trata de una investigación —aún en curso- donde se reconstruye y analiza los procesos culturales que entrelazaban artes, juventudes, mujeres y políticas en los años de la última dictadura (décadas de 1970 y 1980), que se centra en Córdoba (Argentina) y sus redes internacionales. Cuenta con el apoyo del Consejo Nacional de Investigaciones Científicas y Técnicas (Conicet) y del programa de subsidios SeCyT de la Universidad Nacional de Córdoba.

* Doctora en Historia, Licenciada y Profesora en Historia por la Facultad de Filosofía y Humanidades de la Universidad Nacional de Córdoba. Investigadora adjunta del Consejo Nacional de Investigaciones Científicas y Técnicas (Conicet) y profesora concursada en la Escuela de Historia de la Universidad Nacional de Córdoba en Argentina. 


\section{Resumen}

En este artículo, se reconstruyen las presencias femeninas emergentes en un salón artístico desarrollado anualmente durante la última dictadura argentina, donde Córdoba entrelazaba redes locales, nacionales e hispanoamericanas. Como hipótesis, se sostiene que en el campo artístico de las décadas de 1970 y 1980 prevaleció una pirámide jerárquica de posiciones, compuesta por tres escalones de artistas: jóvenes en la base, reconocidos en una posición intermedia y consagrados en la cúspide. En ese marco, el salón visibilizaba una composición pluralista en los concursantes aceptados, pero las distinciones (económicas y simbólicas) eran adjudicadas reiteradamente a obras de autores mayores y masculinos. Mediante herramientas conceptuales de historia cultural y estudios de género, se exploran las generalidades del salón dentro de la política cultural y se profundiza en el análisis del concurso escultórico, donde "lo femenino" existía, no solo como objetos representados por varones, sino en estrategias creativas de mujeres escultoras.

Palabras claves: artes; androcentrismo; escultura; última dictadura argentina.

\section{Abstract}

This article reconstructs the emerging female presences in an art hall held annually during the last Argentine dictatorship, where the city of Córdoba intertwined local, national and Hispanic American networks. As a hypothesis it is argued that in the artistic field of the 1970s and 1980s prevailed a threelayer pyramidal hierarchy: the young, people at the base, the recognized ones at a mid position and the consummate artists at the to In this context, the art hall showed a pluralistic composition among accepted contestants; however the honors (economic and symbolic) were repeatedly awarded to works produced by male and older authors. The generalities of the hall are explored within cultural politics through conceptual tools of Cultural History and Gender Studies. Also, a further analysis of the sculptural competition is done where "the feminine" existed not just as objects represented by men but in the creative strategies of female sculptors.

Keywords: arts; androcentrism; sculpture; last argentinean dictatorship.

\section{Resumo ${ }^{1}$}

Neste artigo se reconstroem as presenças femininas emergentes num salão artístico realizado anualmente durante a última ditadura argentina, onde a cidade de Córdoba entrelaçava redes locais, nacionais e hispano-americanas. Como hipótese defende-se que no campo artístico das décadas de 1970 e 1980 prevaleceu uma pirâmide hierárquica de posições, integrada por três degraus de artistas: jovens na base, reconhecidos numa posição intermediaria, e consagrados no topo. Nesse contexto, o salão expunha uma composição pluralista nos concorrentes aceitados, mas as distinções (econômicas e simbólicas) eram outorgadas reiteradamente a obras de autores maiores e masculinos. Por meio de ferramentas conceptuais de Historia Cultural e Estudos de Gênero se exploram as generalidades do salão dentro da política cultural e se aprofunda a análise do concurso de esculturas, aonde "o feminino" existia não só como objetos representados por homens como também em estratégias criativas de mulheres escultoras.

Palavras chave: artes; androcentrismo; escultura; última ditadura argentina 
Y si la historia estuviera tan llena de huellas, fantasmas — todos ellos "olvidos," desde ya- ¿no se podría contar diferente?

María Laura Rosa

\section{Enfoques y contextos}

Para analizar un caso local, inscripto en una tradición occidental de dominación masculina que condicionó desde los macrocosmos sociales hasta los microcosmos artísticos (Haraway 1995; Bourdieu 2000, 2003), recurriremos a una historia cultural transdisciplinaria que combina estudios de género, historia y sociología del arte (Myers 2002; Rosa 2008). Como explica Haraway $(1995,324)$, uno de los mayores desafíos es encontrar alternativas frente a un modelo científico tradicional donde

el sistema sensorial ha sido utilizado para significar un salto fuera del cuerpo marcado hacia una mirada conquistadora desde ninguna parte. Esta es la mirada que míticamente inscribe todos los cuerpos marcados, que fabrica la categoría no marcada que reclama el poder de ver y no ser vista, de representar y de evitar la representación. Esta mirada significa las posiciones zno marcadas de Hombre y de Blanco uno de los muchos tonos obscenos de la objetividad a oídos feministas en las sociedades dominantes científicas y tecnológicas, postindustriales, militarizadas, racistas y masculinistas.

En contraposición, la autora propone la búsqueda de "conocimientos situados", paradójicos y críticos, encarnados en sujetos con —al menos— doble visión que habitan cuerpos entendidos como nudos generativos materiales y semióticos. Su "óptica como política del posicionamiento" plantea distintas posibilidades de instrumentos metodológicos: interpretación, traducción, tartamudeo, comprensión parcial y descodificación (Haraway 1995, 332).

Un primer paso posible para estudiar la presencia de las mujeres en un salón artístico trans-local de la última dictadura argentina es indagar sobre las "imágenes femeninas" circulantes en el macrocosmos de aquel régimen desplegado entre 1976 y 1983, el cual involucró procesos políticos, económicos, sociales, culturales y artísticos. ${ }^{2}$ Como explica Pollock (1991, 107): “En la cultura dominante no existen 'imágenes de la mujer'. Existen significaciones masculinas representadas por medio de la exhibición de signos corporales".

La sección "Siempre la mujer", del diario con mayor tirada en Córdoba durante aquella coyuntura — La Voz del Interior - permite conocer algunos valores que regían la socialización femenina durante la dictadura cívico-militar. El 21 de septiembre de 1980, en el marco de la fiesta oficial por el Día de la Juventud donde se elegía a la reina de la primavera, ese periódico reproducía una pintura renacentista de Botticcelli (especialmente, fragmentos sobre Venus), recitando como canon de belleza el modelo corporal ario. ${ }^{3}$ Dos años después, en similar marco de festividades, ese diario publicaba cinco avisos con textos e imágenes sugerentes ( $L a$ Voz del Interior, 26 de septiembre de 1982): "En busca de la silueta perdida", "La belleza nuestra de cada día", una reseña sobre las joyas de la actriz Catherine Denueve (cuyo retrato exhibía un vestido del siglo XIX), una nota sobre niñez y una publicidad de muebles para el hogar. Así, el mandato femenino que irrumpía en la prensa sugería el sometimiento a disciplinas alimenticias y gimnásticas para arribar a "un cuerpo ideal," la preponderancia de la cosmética facial (donde 
una foto mostraba a una mujer haciendo un tratamiento a otra fémina que se miraba al espejo), la importancia del ropaje y las alhajas en su re-presentación como objetos estéticos-visualeseróticos y la afirmación de los roles tradicionales de "madre y ama de casa". El "estereotipo femenino" decimonónico (Barrancos 2007, 12) se recitaba en la última dictadura a través de imágenes y textos difundidos en dispositivos, como fiestas oficiales, medios de comunicación y manuales de formación moral-cívica del sistema educativo (Postay 2004). El régimen instalado en 1976 implicó un freno, entre otras cosas, para las posibilidades femeninas abiertas con las "revoluciones silenciosas y las utopías estridentes" que habían irrumpido desde la década de 1960 en algunos sectores sociales de Argentina (Barrancos 2007, 209).

Este artículo procura contribuir en el estudio de los procesos culturales desarrollados en aquella coyuntura, retomando algunos senderos transitados y adentrándonos en nuevos recorridos (como la presencia de mujeres). Paralelamente, frente a un predominio de abordajes focalizados en la capital federal (Buenos Aires), nuestra historización profundiza en el caso de Córdoba. ${ }^{4} \mathrm{~A}$ partir de allí, podremos explorar prácticas artísticas escasamente conocidas que entrelazaban hilos de una compleja trama entre la provincia, el país y el contexto internacional.

En investigaciones precedentes, abordamos la reconstrucción histórica de algunas "políticas culturales" y ciertos "intersticios de resistencia" desarrollados en la dictadura (Miller y Yúdice 2004; Foucault 1992), centrándonos en dos temas: artes plásticas y juventudes en Córdoba. Respecto del régimen, corroboramos que el imaginario oficial defendía la existencia de una "guerra integral contra el comunismo", la cual, según la visión hegemónica, se libraba tanto en planos materiales como "espirituales". Así, junto con la fase destructiva que hizo "desaparecer" a aquellas personas e ideas consideradas "subversivas," el Gobierno desarrolló una acción constructiva que proclamaba la re-fundación de una cultura nacional defensora de los "auténticos valores de la civilización occidental y cristiana" (Invernizzi y Gociol 2002; González 2014b). En ese marco, desde los inicios del régimen, proliferaron variadas políticas culturales que tuvieron entre sus principales focos de acción las artes. ${ }^{5}$

En el discurso dictatorial, la palabra arte era en general utilizada para designar acciones y obras que respondían a dos rasgos prioritarios: por un lado, aspirar y lograr belleza; por otro, producir una experiencia estética en el receptor (Tatarkiewicz 2002, 56). En las mentalidades autoritarias, ambos significados (que encontraban en las pinturas de paisaje y en las esculturas de pedestal dos piezas predilectas) se mixturaban con imaginarios bélicos y religiosos que dotaban el arte de funciones espirituales. Así, una revista oficial denominada Guía de Córdoba Cultural, publicada en febrero de 1981, sentenciaba: "El arte que no nos eleva y acerca a Dios no merece siquiera el nombre de Arte". Esta máxima recitaba una frase de 1934 del pintor paisajista Fray Guillermo Butler, la cual es indicativa del clima cultural vivenciado en las performances (Schechner 2000) desplegadas por el Gobierno para conmemorar el Aniversario Fundacional de Córdoba. Fue en esas celebraciones donde, entre otros eventos artísticos, adquirió una visibilidad destellante, desde 1977, un nuevo concurso de artes plásticas: el Salón y Premio Ciudad de Córdoba.

Esas puestas en escena concretadas por los dictadores locales eran procesos culturales importantes que precedieron y prosiguieron al periodo autoritario, pero evidenciaron un apogeo especial entre 1980 y 1983, cuando los actos de un día (el tradicional 6 de julio que evocaba la fundación colonial española de 1573) se ampliaron a una Semana de Córdoba. En esas fiestas oficiales, lo que se re-construía anualmente era la propia identidad cultural cordobesa, y también argentina, donde el mito de origen hispánico servía para re-fundar un imaginario 
gubernativo anclado en la trilogía de Dios, Patria y Familia. Allí confluían dispositivos simbólicos y materiales mediante los cuales se reinventaba la tradición que conectaba a la ciudad y al país con "la civilización occidental y cristiana" de Hispanoamérica. Entre las distintas actividades materializadas por esos rituales cívicos, los eventos artísticos ocuparon un lugar constante y destacado; especialmente, las ediciones anuales de un nuevo salón de artes plásticas instituido en $1977 .{ }^{6}$

\section{El Salón entre 1977 y 1981: generalidades del concurso y presencias femeninas}

La posibilidad de reconstruir históricamente los "hilos" y la trama cultural del Salón y Premio Ciudad de Córdoba se ve condicionada en el siglo XXI por la existencia de "huellas" documentales escasas y dispersas (Ginzburg 2006). Solo algunos de los catálogos y pocas obras premiadas se encuentran en la sede principal que albergaba el concurso: el céntrico Museo Municipal de Bellas Artes Dr. Genaro Pérez. El relevamiento de fuentes periodísticas epocales permitió acceder a otros datos diseminados, mientras las entrevistas con una de las mujeres participantes posibilitaron escuchar recuerdos personales significativos y visualizar imágenes conservadas en archivos individuales. El cotejo de esos documentos permite ir hilvanando un relato que, aunque fragmentario, viabiliza una exploración de las características generales del Salón y de las presencias femeninas allí emergentes.

En cuanto a las generalidades del concurso, observamos que cada ciclo anual del Salón y Premio Ciudad de Córdoba estuvo dedicado a tradicionales disciplinas plásticas que reiteraban su irrupción cada tres años: Pintura, Dibujo-Grabado y Escultura (cuyas primeras ediciones se dieron en 1977, 1978 y 1979, respectivamente). Si bien el Salón estaba restringido a artistas cordobeses, los jurados estuvieron regularmente integrados, no solo por agentes locales, sino por representantes de instituciones hegemónicas del país con sede central en Buenos Aires, como el Museo Nacional de Bellas Artes y la Asociación Argentina de Críticos de Arte. Así, en el catálogo de 1977, el Arq. López Feit (titular de la Subdirección de Cultura con sede en el Museo Municipal de Bellas Artes Dr. Genaro Pérez) agradecía el apoyo del Fondo Nacional de las Artes, mientras manifestaba su interés respecto de que el "mensaje colorido de los artistas cordobeses recorriera los centros culturales de todo el país." Efectivamente, las redes con otras ciudades argentinas se acrecentaron, en algunas ediciones, mediante muestras itinerantes que, luego de la exposición inaugural, hacían circular las obras seleccionadas por otras sedes provinciales. Por ejemplo, un certificado de 1978 registraba que los dibujos de Ángel Herrera habían integrado la exhibición colectiva del Salón tanto en museos de otras ciudades (Santa Fe, Paraná y Rosario) como en la Casa de Córdoba ubicada en Buenos Aires.

En relación con los artistas que participaban del Salón y Premio Ciudad de Córdoba, el texto de 1977 explicitaba el objetivo de "reunir en un común fervor artístico a los valores consagrados con aquellos que inician su itinerario." Pero, en la práctica, este concurso devenía un dispositivo de inclusión-exclusión que reconstruía, en cada edición, la distinción de unos pocos (Bourdieu 2003). Un jurado de renombre nacional e internacional era convocado por el Gobierno cordobés para aplicar dos filtros de selección. En principio, del conjunto de aspirantes a concursar se aceptaba, en general, a menos de 50 \%; por ejemplo, el Salón de 1981 (dedicado a Dibujo-Grabado) solo admitió las obras de 40 productores de los 96 postulantes. Posteriormente, un segundo filtro (las premiaciones de las obras) reducía en mayor grado el 
número de los ganadores, ya que, anualmente, se otorgaban dos premios adquisición (donde la diferencia monetaria entre el primer y segundo puesto se correspondía con la asignación de una plaqueta dorada y plateada, respectivamente), dos menciones con opción a compra y de dos a cuatro menciones honoríficas.

Si bien el concurso solo explicitaba un requisito de pertenencia geográfica (ser nacido o residir en Córdoba), otras restricciones limitaban el acceso y el triunfo dentro del Salón y Premio Ciudad de Córdoba. Los currículos de los autores, cuyas obras fueron premiadas, eran reproducidos por los catálogos y nos permiten visualizar un proceso de distinción circular que, en general, reafirmaba el reconocimiento de artistas ya consagrados en el campo, quienes evidenciaban una trayectoria local o inter-nacional que superaba los diez años, exposiciones museográficas individuales y colectivas, exhibiciones en galerías hegemónicas, selecciones o premiaciones en salones. Así, la posibilidad de devenir distinguido en el Salón y Premio Ciudad de Córdoba estaba frecuentemente restringida a los artistas "mayores", cuya antigüedad etaria, por lo general, se correspondía con la posesión de los capitales culturales y simbólicos demandados. Paralelamente, un último requerimiento (la preparación académica) nos introduce en una de las excepciones significativas de este mundo del arte: si bien encontramos una mayoría de graduados, el Salón no solo aceptó sino que también premió a algunos estudiantes y autodidactas. Sin embargo, esas "irregularidades" aparecían restringidas genéricamente a los agentes masculinos, mientras el polo opuesto mostraba algunos casos de mujeres con doble titulación que no llegaban a ser premiadas.

Esa tendencia del Salón provincial se correspondía con un proceso cultural más amplio observable tanto en el microcosmos de las artes plásticas (local e internacional) como en el macrocosmos de la sociedad cordobesa de la década de 1970 e inicios de la de 1980: un predominio del androcentrismo. ${ }^{7}$ Al respecto, Herrera y Menas (2017) coinciden en afirmar que, en la dictadura, entre los alumnos de artes existía un número de mujeres que igualaba (y varias veces superaba) a la cantidad de hombres. Por su parte, el relevamiento de distintos catálogos del Salón y Premio Ciudad de Córdoba que se encontraban dispersos en archivos públicos y privados evidencia una minúscula presencia de artistas femeninas y escasísimas ocasiones en que sus obras fueron premiadas.

El Salón de Pintura de 1977 visibilizaba nombres de 7 mujeres entre los 42 artistas seleccionados, los cuales eran mencionados (entremezclados con nombres masculinos) en orden alfabético: Silvina Bottaro, Anahí Cáceres, María Oviedo, Ángela Rojo, Susana Rota, Elba Torres de Torres y Moira Wieland. ${ }^{8}$ De este subgrupo solo un trabajo de Bottaro fue distinguido con un tercer premio, asignado excepcionalmente por el Fondo Nacional de las Artes. En 1978, la sección Dibujo reunió a 3 mujeres dentro de los 24 concursantes (Silvia Germán, Nora Montes y Leonor Sánchez), mientras la sección Grabado contenía 3 nombres femeninos dentro de 8 seleccionados (Lina Bevilacqua, María Cristina Rame y Margarita Selva). ${ }^{9}$ Montes y Rame recibieron la segunda mención en cada sección. Respecto del Salón de Escultura de 1979, no fue posible hallar el catálogo. El Salón de Pintura de 1980 evidenció la presencia de 4 mujeres dentro de los 42 artistas seleccionados: Marcela Mérida, Nora Montes, Beatriz Rodríguez Tarragó y Rosa Tinti. ${ }^{10}$ Las dos últimas recibieron menciones honoríficas por sus cuadros. En el Salón de 1981, dedicado a Dibujo y Grabado, encontramos 6 mujeres dibujantes dentro de 28 participantes (Anahí Cáceres, María de la Colina, Emma Gargiulo, Nora Montes, Beatriz Rodríguez Tarragó y Rosa Ana Tinti) y 6 grabadoras en un total de 12 concursantes (Beatriz Beltrán, María A. Candiani, Celia Caturelli, María C. Fasah, Nina Juárez y Ana Bettini de Lalubie). ${ }^{11}$ En cuanto 
a las obras de esas autoras, solo un dibujo fue premiado, mientras ninguno de sus grabados recibió distinción. Sobre el Salón de Escultura de 1982, donde encontramos 4 mujeres dentro de un grupo de 15 productores, profundizaremos en los siguientes subtítulos. Finalmente, el Salón de Pintura de 1983 visibilizó a 6 mujeres dentro de 29 concursantes: Olga Cabello, Selva

Gallegos, Silvia Germán, Rosa Tinti, Ángela Protto de Rojo y Beatriz Rodríguez Tarragó. ${ }^{12}$ Ninguna de sus obras recibió distinción.

Esa escasez de nombres femeninos en el listado de artistas seleccionados también se reiteraba dentro de los jurados. Los agentes convocados por el Gobierno para ejercer esa función ascendieron, en general, a nueve integrantes. Mientras en 1977 no estuvo presente ninguna mujer y en 1978 participaron tres (“Lic. Josefina Ramón Casas, Sra. Ana Bettini de Lalubie y Sta. Ana María Moncalvo"), lo habitual era la existencia de una única invitada. Ese fue el caso del Salón de Pintura de 1980 y del Concurso de Dibujo-Grabado de 1981, donde primero Nelly Perazzo (1925-) y luego Ana Moncalvo (1921-2009) se desempeñaron como representantes de la Municipalidad de Córdoba. Ambas pertenecían al campo artístico de Buenos Aires y, para la década de 1960, concentraban reconocimiento tanto en el país como en el exterior. ${ }^{13}$ Cabe destacar que Nelly, como tantas otras mujeres en las décadas de 1970 y 1980, era conocida por su apellido de casada (Perazzo) y solo excepcionalmente por su apellido de soltera (Kirger).

En los nombres de algunas artistas y jurados participantes del Salón y Premio Ciudad de Córdoba, encontramos el uso unitario del apellido de casada o la utilización de dos apellidos vinculados con la preposición "de". Según señala el posestructuralismo, el lenguaje desempeña un papel central en la construcción de la subjetividad (no solo) femenina (Rosa 2008, 158); en este caso, esas formas de nominación connotarían pertenencia de la mujer respecto del marido. Paralelamente, bajo la aparente homogeneidad del término artista, se invisibilizaba, entre otras cosas, la reproducción del androcentrismo social que frecuentemente desplazaba a las mujeres del escalón de los creadores y las restringía a roles secundarios o peyorativos, como los de parientes "de" varones hegemónicos, consumidoras, docentes, promotoras de arte u objetos de representación visual-eróticos (Méndez 1995; Blázquez 2007). Esas prácticas se desplegaban en diversas áreas de las artes plásticas, pero adquirían características particulares en la escultura; un conjunto de procesos que analizaremos en las siguientes secciones.

\section{2, Salón de Escultura en contextos posbélicos}

En 1982, la inauguración del Salón y Premio Ciudad de Córdoba volvió a concretarse dentro de los homenajes oficiales de inicios de julio que rememoraban la fundación hispánica de la ciudad. No obstante, irrumpía una discontinuidad central que distanciaba esos actos de los anteriores festejos: en las semanas previas, la nación había sido derrotada por Inglaterra en la única guerra convencional librada durante el siglo XX, acontecimiento donde 12000 jóvenes soldados alcanzaron una participación protagónica. Esa inmediata posguerra significaba, para algunos, una posibilidad esperanzadora (la caída del régimen y la transición democrática); sin embargo, los argentinos, en general, estaban imbuidos en emociones de decepción, traición y estupor (Lorenz 2006). Esas "estructuras de sentimiento" (Williams 2000) podían observarse en distintos ámbitos sociales; entre ellos, en el Salón y Premio Ciudad de Córdoba. 
La exhibición de las obras seleccionadas y premiadas se inauguró el 5 de julio en el Museo Municipal de Bellas Artes Dr. Genaro Pérez. El catálogo informaba que allí permanecería hasta mediados de agosto, cuando la exposición sería trasladada a los centros culturales periféricos. Este desplazamiento por los barrios capitalinos emerge como novedad de 1982 y puede ser interpretada como un intento de ampliación de públicos. No obstante, las fuentes relevadas no permiten dar cuenta del número o composición de los posibles asistentes, sino que solo aportan algunos datos sobre los funcionarios que concurrieron a la inauguración. ${ }^{14} \mathrm{La}$ presencia de autoridades en la performance de apertura era signo de la importancia oficial asignada al evento: del ámbito provincial, el gobernador Pellanda y el director de actividades artísticas (Oscar Frávega); del sector municipal, el intendente Cafferata, el secretario de gobierno (Dr. Barbará), la subsecretaria de cultura (Arq. Marta Deltrozzo) y el director de promoción cultural, señor Manuel Solís (Guía de Córdoba Cultural, agosto de 1982).

Un diario dominical celebraba la iniciativa y aportaba un dato importante que no solía adquirir visibilidad en documentos internos del campo artístico, donde se re-producía la práctica de una "economía denegada" (Bourdieu 2003): la escultura era definida como una "actividad plástica costosa y relegada de los salones locales", condicionantes que explicarían la "escasez de sus cultores" (La Voz del Interior, 4 de julio de 1982). No es un dato menor que el importe monetario de los premios solo adquiriera explicitación en los periódicos que convocaban el concurso, pero era invisibilizado en los catálogos; quizá, para reafirmar su in-valorable costo en cuanto "bienes espirituales". Un diario del bimestre anterior (La Voz del Interior, 24 de mayo de 1982) informaba que los premios ascendían a $\$ 8000000$ y $\$ 5000000$ para el primer y segundo puesto, respectivamente; mientras se adjudicarían "dos menciones con opción a compra". Paralelamente, se reiteraba que todos los primeros premios pasarían a integrar la colección del museo. Como requisitos, se señalaba que el concurso estaba restringido a escultores radicados en la provincia con un mínimo de dos años de residencia, el tamaño mayor de las obras no podía exceder los 2 m y la recepción de las piezas cerraría el 24 de junio.

En cuanto al jurado, el catálogo muestra la persistencia de representantes de varias instituciones culturales emergentes en ediciones anteriores, las cuales daban cuenta de redes entre entidades locales y nacionales: Prof. Vicente Caride (Asociación Argentina de Críticos de Arte), Prof. Jorge Zerdá (Museo Nacional de Bellas Artes), Sr. Noé Nojechowicz (Fondo Nacional de las Artes), Prof. Carlos M. Funes (Municipalidad de Córdoba), Prof. Víctor M. Infante (Gobierno de la Provincia), Prof. Marta Giraudo de Fabián (Universidad Nacional de Córdoba), Prof. Horacio Suárez por los Artistas Plásticos Asociados de Córdoba, Prof. Miguel Ángel Budini (por los participantes) y el Sr. Manuel Solís (director de promoción cultural municipal) como veedor y jurado de desempate. El Diccionario de artistas plásticos de Córdoba (Moyano 2010, $125,448)$ registra a algunos de esos agentes: sobre Budini (1911-1993) y Suárez (1917-) se informa que eran escultores reconocidos a inicios de la década de 1980, habían egresado de la Escuela Provincial de Bellas Artes y se desempeñaban como docentes tanto de ese establecimiento como de la Escuela de Artes de la Universidad Nacional de Córdoba; en cuanto a Solís (1936-), se reseña una trayectoria tanto escultórica como de gestión, debido a su desempeño como "Director de Cultura Municipal de 1981 a 1983" (Moyano 2010, 437). Infante (1915-2010) y Funes (1933-) compartían el antecedente de haber ejercido como directores de la mayor institución museográfica cordobesa de aquellos años (el Museo Provincial de Bellas Artes Emilio Caraffa): uno, entre 1953 y 1963; el otro, entre 1967 y 1982 (Museo Caraffa 2017). Caride 
(1913-1994) y Nojechowicz (1929-1998) poseían prestigio en el país y en el exterior, siendo distinguidos con los Premios Konex en 1982 por sus trayectorias como jurado y pintura surrealista, respectivamente (Fundación Konex 2017). En cuanto a Zerdá, no localizamos ningún dato.

Conjuntamente, sobre la única integrante femenina del jurado (Marta Giraudo de Fabián) encontramos escasa información: el catálogo de 1982 registra una titulación de profesora que la vincula a la Universidad Nacional de Córdoba. Detectamos dos referencias más sobre ella recién en el siglo XXI, las cuales la ubican como escultora: por un lado, dentro de los eventos culturales organizados por la Municipalidad en 2006 (Muestra de Esculturas en Paseo de las Artes); por otro, en una exposición de artistas invitados, quienes en posición de amigos acompañaban la Muestra Homenaje de 2017 a la pintora Rosa Tinti en la re-inauguración del Museo de las Mujeres. ${ }^{15}$

El acta del jurado informaba que se había reunido el 26 de junio en el Museo Municipal de Bellas Artes Dr. Genaro Pérez. Como en ediciones anteriores, aplicó dos filtros de selección: por un lado, la aceptación de 15 participantes (con 2 esculturas cada uno) dentro de un conjunto de 25 aspirantes; por otro, la distinción de 4 obras dentro las 30 piezas concursantes. El documento registraba algunos des-acuerdos: mientras seis jurados nacionales y provinciales elegían adjudicar el primer premio a Miguel Bondone por su obra Comunicación, dos opiniones locales se inclinaban hacia Carlos Zárate por su obra Éxtasis. Esa disputa se resolvió por voto mayoritario; no obstante, la posición ante el segundo premio presentó una paridad: cuatro agentes de instituciones provinciales votaban por Éxtasis, mientras tres representantes porteños y uno municipal lo hacían por el trabajo de Oscar Páez. En este caso, el voto de Solís ratificó la decisión de sus colegas mediterráneos. Paralelamente, se explicitaba que, por unanimidad de votos, la primera mención había recaído en el citado Páez por su obra Péndulo V. Respecto de la segunda mención, volvía a emerger una disparidad resuelta por mayoría: cinco optaban por entregarla a Martha Bersano por su obra El grito, mientras tres preferían a Carmen Raurich-Saba por su pieza Vino una paloma que comenzó un rumor de lamentos.

\section{Escultores, ¿pirámide de géneros, generaciones y clase social?}

Ser mujer y ser escultora pareciera que no es muy compatible. La escultura necesita de un estado físico. Necesitás fuerza. Si no tendrías que tener un... Bueno tendríamos que partir desde una economía fantástica, entonces vos tenés muchos ayudantes.

Martha Bersano

Según nuestra hipótesis de lectura, en el campo de las artes plásticas, durante las décadas de 1970 y 1980 en Córdoba, encontramos una pirámide jerárquica de posiciones, compuesta por tres escalones principales: artistas jóvenes en la base, artistas reconocidos en una posición intermedia y artistas consagrados en la cúspide. En esas estratificaciones, se producía una singular mixtura entre clasificaciones etarias, genéricas y clasistas: mientras la base se caracteri- 
zaba por una composición pluralista, a medida que nos acercamos a la cúspide las condiciones de acceso y permanencia devenían reservadas para los productores "mayores", masculinos y pertenecientes a los sectores sociales dominantes. Esas prácticas de diferenciación pueden observarse, por ejemplo, en el Salón de Escultura de 1982.

El catálogo del Salón y Premio Ciudad de Córdoba publicaba resúmenes curriculares sobre los cuatro autores de las obras premiadas, los cuales aportaban pistas en torno a los criterios valorados por el jurado. Sobre el resto de los once escultores, cuyos trabajos habían sido seleccionados para concursar (pero no obtuvieron ninguna distinción), no reseñaba datos de sus biografías profesionales, solo aportaba sus patronímicos junto con nombres y reproducción de sus dos obras. Para conocer algunos detalles de esas trayectorias in-visibilizadas, triangularemos la información del catálogo con otros documentos de la década de 1980 y con una investigación reciente de Moyano (2010): el Diccionario de artistas plásticos de Córdoba. Según el catálogo,

Miguel Ángel Bondone. Nació en Bell Ville. En 1963 comenzó su tarea como escultor, abocándose definitivamente a la misma desde 1970. Es autodidacta. Ha realizado diversas exposiciones individuales y colectivas en Buenos Aires y Córdoba. 1978: Primer Premio del Salón de Escultura de Artistas Plásticos Asociados de Córdoba.

Carlos Hipólito Zárate. Nació en Olpas, La Rioja en 1928 [...] Egresó como Profesor de Dibujo y Escultura de la Escuela Provincial de Bellas Artes. Distinciones: 1.er Premio de Escultura, 1952 Acción Católica Argentina; 1964, Salón de Córdoba; 1974 Artistas Plásticos Asociados de Córdoba [...] Exposiciones: desde 1966 en Buenos Aires y Córdoba. Sus obras se encuentran en colecciones privadas del país y el extranjero. Obras públicas: Busto de Jerónimo Luis de Cabrera (piedra), Córdoba, 1969; Monumento a la Madre (mármol), La Rioja, 1965 [...]

Oscar Enrique Páez. Autodidacta; comienza su obra en 1977. 1978, 1.er Premio en el Salón Juvenil. 1979, mención honorífica del jurado en el Salón y Premio Ciudad de Córdoba. 1980, premio Fundación Alejandro Shaw en la ANBA [Academia Nacional de Bellas Artes] [...] 1981, 1. er Premio en el $\vee$ Salón Anual de Constitución. Ha participado en numerosas muestras colectivas en Córdoba y en Buenos Aires.

Marta Bersano [sic]. Profesora de Dibujo y Escultura, egresada de la Escuela Provincial de Bellas Artes en 1978. Formó parte del equipo de Horacio Suárez para la realización del Monumento al General Manuel Belgrano y a Pedro Nolasco y los murales de Plaza España. Participó en muestra colectiva de egresados de la Escuela Provincial de Bellas Artes y colectiva de Artistas Plásticos Asociados de Córdoba. Actualmente ejerce la docencia en institutos de Bell Ville.

(VI Salón y Premio Ciudad de Córdoba, Escultura, cat. ex Córdoba, Museo Municipal de Bellas Artes Dr. Genero Pérez, 1982).

Las edades biológicas de los cuatro distinguidos ascendían, en 1982, a 43 años Bondone (1939-), 54 años Zárate (1928-), 29 años Páez (1953-) y 30 años Bersano (1952-). Adentrémonos en los significados sociales (y, en especial, artísticos) que se entrelazaban con esos datos etarios (Bourdieu 2002). Según el catálogo, los dos premiados compartían una característica: precedentemente, habían obtenido el primer premio en concursos escultóricos organizados por los Artistas Plásticos Asociados de Córdoba, entidad que poseía representación en el 
jurado de 1982. Entre las notas disonantes, se destaca que, mientras Zárate evidenciaba tres décadas de trayectoria (con titulación profesional y muestras tanto en el ámbito nacional como en el extranjero), ${ }^{16}$ el primer galardón recayó en Bondone: agente que presentaba una antigüedad de dos décadas en el medio escultórico y una condición de autodidacta. ${ }^{17}$

Esta última calificación nos introduce en una de las peculiaridades del campo plástico contemporáneo: el reconocimiento de un productor como artista y de sus productos como obras de arte depende frecuentemente de la certificación académica; pero, a veces, emergen agentes con capitales culturales (incorporados y objetivados) que carecen de esa formación institucional. La figura del autodidacta puede remitir a destrezas artísticas adquiridas mediante un proceso de aprendizaje individual o informal (por ejemplo en talleres particulares), pero también suele asociarse a la posesión de "un don". Esa aptitud sobrenatural sería "descubierta por el gusto innato" de algunos agentes hegemónicos del campo (como aquellos convocados a integrar el jurado de un salón oficial) y así da vida a un círculo de distinciones que se acerca a la ideología carismática (Bourdieu 2003).

La predilección de la obra de un autodidacta por sobre un egresado académico se reiteró en las menciones que condecoró la obra de Oscar Páez con el primer lugar y la de Martha Bersano con el segundo. En esta ocasión, estamos frente a dos sujetos de la misma generación que contaban con exposiciones en el lustro precedente y que eran calificados por la política cultural oficial como jóvenes artistas. ${ }^{18}$ Si bien compartían el linde de los 30 años, los currículos del salón diferenciaban que, a fines de la década de 1970, Páez ya había recibido premios nacionales y locales (como la mención honorífica en el Salón y Premio Ciudad de Córdoba de Escultura en 1979), mientras Bersano egresaba académicamente, luego de siete años de estudio, como Profesora de Dibujo y Escultura.

Triangulando las huellas del catálogo con otras fuentes, percibimos redes que conectaban a jurados (como Suárez) y a artistas distinguidos (como Zárate y Bersano) con dos instituciones académicas de Córdoba: una fundada en 1896 en la capital cordobesa (la Escuela Provincial de Bellas Artes Dr. Figueroa Alcorta); otra, inaugurada en 1942 en el interior cordobés (la Academia de Bellas Artes Fernando Fader) (Escuela Superior de Bellas Artes Fernando Fader 2017). Otro eje de problemáticas de distinción se abre si observamos que, a diferencia de la invisibilidad de Bondone y Zárate en el Diccionario de artistas plásticos de Córdoba, ese texto de Moyano $(2011$ 101, 355) sí registra a Bersano y a Páez.

Sobre los otros once escultores, cuyas obras no fueron premiadas, encontramos datos fragmentarios y dispersos. Cinco de esos agentes poseían dos particularidades compartidas: ser clasificados por la política cultural dictatorial como jóvenes artistas y ser reconocidos por la historia del arte reciente dentro del conjunto de los artistas plásticos de Córdoba (Moyano 2010). Nos referimos a María Belloni (1951-), Sara Galiasso (1946-), Marcelo Hepp (1946-), Miguel Sahade (1940-2010) y Leonardo Kilstein (1942-2004). Por su parte, tanto Carlos Díaz Navarro (1944-) como Leopoldo Garrone (1916-) tienen visibilidad en el citado Diccionario, mientras están ausentes de las muestras y los salones juveniles que organizaba el gobierno autoritario en Córdoba. Sobre Carmen Raurich-Saba (1920-) solo la prensa ibérica nos informa que era una escultora española que se había radicado en Córdoba en la década de $1950 .{ }^{19}$ Las dudas se multiplican en torno a Roberto Álvarez, Ismael Criado y Guillermo Lotz: ninguno de los tres aparece como participante en las objetivaciones artístico-juveniles dictatoriales ni es rescatado por el discurso historiográfico reciente. ${ }^{20}$ 
Esas presencias y ausencias invitan a esgrimir explicaciones distintas que abarcan desde el alejamiento voluntario del quehacer escultórico hasta los procesos de exclusión propiciados por la propia dinámica del campo, donde solo una minoría conseguía permanecer y ascender en la carrera artística. En este campo, la posición de joven artista podía ser ocupada por un tiempo limitado: la "provisionalidad de la juventud" (Levi y Schmitt 1996) la hacía una situación transitoria, donde los límites de la edad biológica lindaban, en general, entre los 18 y 40 años. Así, de una mayoría de jóvenes creadores que participaban en concursos y muestras de las décadas de 1970 y 1980, solo un escaso número de sujetos logrará ser reconocido y perdurar como un artista consagrado que tendrá, entre otros capitales, premios y exposiciones individuales durante su edad "adulta".

Combinando enfoques de historia cultural y estudios de género, podemos decir que el Salón propiciaba distinciones no solo etarias sino también genéricas. La adjudicación de la segunda mención (es decir, el cuarto y último puesto) a una joven mujer parece corresponderse con la escasa participación femenina en el Salón y Premio Ciudad de Córdoba 1982, donde, dentro del conjunto de los quince escultores aceptados, ellas solo ascendían a cuatro autoras. En orden alfabético de sus apellidos: María Teresa Belloni, Martha Bersano, Sara Galiasso y Carmen Raurich-Saba. La historia del arte local permite saber que, en 1982, las tres primeras se encontraban transitando los 30 años y habían adquirido titulaciones académicas, mientras la prensa ibérica posibilita deducir que la edad de aquella escultora española traspasaba los 60 años.

Según los registros de Moyano $(2010,91,101,223)$ sobre las tres primeras artistas, en 1973, Belloni finalizó sus estudios en la Escuela Provincial de Bellas Artes y en 1980 obtuvo el título de Licenciada en Escultura por la Escuela de Artes de la Universidad Nacional de Córdoba con premio al mejor promedio. Mientras Bersano había egresado de la Escuela Provincial de Bellas Artes en 1978 como Profesora de Dibujo y Escultura. Galiasso, por su parte, se había graduado en la Universidad Nacional de Córdoba como abogada en 1970 y como Licenciada en Escultura en 1980. El testimonio reciente de Bersano, la productora galardonada en aquel VI Salón y Premio Ciudad de Córdoba de 1982, aporta una mirada crítica sobre la situación de las mujeres en aquel campo escultórico:

ESCULTORA: Mucha gente tan talentosa que he visto pasar por la Escuela, en veintiséis años [de docencia] he visto gente increíble, y después no existe más. Creo que es porque se necesita como de una fortaleza especial para estar en el arte. No sé, será, sobre todo, por la escultura, la condición de mujer, que influye mucho también.

HISTORIADORA: ¿En favor o en contra para la escultura?

ESCULTORA: Creo que siempre es en contra. Creo que la sociedad por más que digamos "esto o aquello," "liberación de la mujer"...

HISTORIADORA: Hay estructuras que continúan.

ESCULTORA: Hay estructuras que están ahí muy solidificadas. Entonces, ser mujer y ser escultora pareciera que no es muy compatible. La escultura necesita un estado físico. Necesitás fuerza. Si no tendrías que tener un... Bueno tendríamos que partir desde una economía fantástica, entonces, vos tenés muchos ayudantes, los ayudantes hacen las cosas bajo tu supervisión. Esa es otra situa- 
ción que no es la mía, por ejemplo... Lola Mora sin todos sus ayudantes no hubiera hecho nada. Ella no se pasó puliendo el mármol, porque hubiera hecho una escultura en su vida. Miguel Ángel tampoco. Entonces, eso de tener ayudantes a mí no me parece para nada peyorativo. (entrevista con Martha Bersano, 6 de septiembre de 2010)

Este fragmento de entrevista nos introduce en dos ejes de variables entrelazadas: clase social y género. Por un lado, Bersano llama la atención sobre las limitaciones económicas que restringían la posibilidad de contratar ayudantes; recurso que la entrevistada considera determinante, por ejemplo, en la mítica figura de una de las primeras escultoras argentinas reconocidas: Lola Mora (1867-1936) (Centro Virtual de Arte Argentino). El alerta sobre los altos costos del trabajo escultórico también era señalado por un cronista epocal (La Voz del Interior, 4 de julio de1982). Por otro lado, la reflexión de Martha nos invita a pensar en un androcentrismo generalizado, especialmente, en el área de la escultura, condicionado por la supuesta "fuerza física" necesaria para trabajar con materiales considerados pesados y "nobles", como el mármol.

Esa percepción personal de la artista puede ser situada en un proceso social mayor. Mediante una milenaria tradición, reinventada en Occidente, se fue cristalizando un binomio que calificó y opuso un "sexo fuerte" (masculino) por encima de un "sexo débil" (femenino). Se trató de complejos procesos de naturalización de la cultura, situaciones donde una invención social perdía su carácter de construcción histórica para devenir algo "universal y normal." La arbitrariedad de ese mecanismo de legitimación circular fue denunciada por investigaciones como las de Haraway (1995), Butler (1999) y Bourdieu (2000) que demostraron cómo ciertos datos biológicos son manipulados para constituirse en garantes "naturales" de un orden social hegemónico. Así, tanto en los microcosmos artísticos como en el macrocosmos social, el agente predominante es masculino, heterosexista, burgués y blanco (De Diego 1999; Rosa 2008).

Conjuntamente, un testimonio actual de Bersano permite pensar que los condicionantes de género y clase social también se combinaban con otros factores (generacionales y de pertenencia a una de las dos academias con sede en la capital cordobesa) que posibilitaban el des-conocimiento entre las mujeres dedicadas a la escultura:

No muchas mujeres estudiaban escultura. En el Profesorado Superior de Escultura de la Escuela Figueroa Alcorta, de 1976 a fines de 1978, fui la única. También por 1979 fui a la Universidad Nacional de Córdoba como concurrente libre y allí estaban estudiando Sara Galiasso, María. T. Belloni, Mora Flores (que murió muy joven), y unas cuantas más que ya no recuerdo.

Marta Giraudo [... . Sí fue, o es aún, escultora. Yo no la recuerdo. Estudié en la F. Alcorta y ella era docente de la Universidad Nacional de Córdoba.

No recuerdo tampoco la obra de Carmen Raurich-Saba. Solo creo conocerla de vista.

Dentro de las modeladoras, como referente anterior la tengo a Clara Ferrer Serrano de quien fui ayudante. (Martha Bersano, correo electrónico a la autora, junio de 2017)

La posibilidad de estudiar formalmente escultura en Córdoba durante la década de 1970 se restringía a dos trayectos principales: mientras en la Escuela Provincial de Bellas Artes se accedía luego de siete años de cursado al título de Profesor de Dibujo y Escultura, en la Escuela de Artes Universitaria se obtenía la titulación de Licenciatura en Escultura luego de cinco años de estudio. Las futuras investigaciones podrán acceder a porcentajes de las diversas disciplinas plásticas que permitan cotejar si el número de escultoras era menor del de egresadas como pintoras y graba- 
doras (dibujo solo aparecía en las titulaciones otorgadas por la Escuela Provincial de Bellas Artes como un elemento primario y común a las otras tres disciplinas). Queda pendiente explorar si en esta ciudad hubo semejanzas o variaciones respecto de la tendencia corroborada para la matrícula femenina en Buenos Aires (Barrancos 2007, 220): un aumento creciente desde la década de 1960. También sería importante profundizar en las vivencias de ambas casas de estudio durante la dictadura en Córdoba, donde, si bien el régimen desplegó intervenciones explícitas y vigilancias encubiertas, los entrevistados coinciden en calificarlas como refugios para la libertad de expresión (González 2014b).

\title{
¿Esculturas "femeninas"? De objetos representados a agentes creativos
}

\author{
En la historia del arte la mujer es Venus, \\ Artemisa, María o Magdalena, objeto de deseo, \\ exaltación, amor o rechazo, pero siempre \\ construcción. Eternamente representada, \\ definida según las modas, modelada según las \\ épocas, siempre objeto, nunca sujeto. \\ María Laura Rosa \\ Las obras de ese salón fueron modeladas y \\ vaciadas en piedra reconstituida [...] No trabajo \\ con base en un título preestablecido (salvo algún \\ concurso con temática). El título surge después \\ que termino una obra.
}

Martha Bersano

El catálogo del concurso de 1982 presentaba, excepcionalmente, una valiosa información, no solo reproducía las cuatro piezas premiadas, sino que también aportaba fotografías sobre el total de obras aceptadas en aquel (treinta esculturas correspondientes al doble envío de los quince agentes participantes). ${ }^{21}$ De ese conjunto, nos detendremos "ante" una veintena de imágenes (DidiHuberman 2008), que dividiremos, operativamente, en tres grupos, para dar cauce a dos objetivos: 1) visualizar las propuestas de todos los concursantes problematizando posibles dis-continuidades y estrategias creativas respecto de los cánones imperantes tanto en el microcosmos como en el macrocosmos, y 2) analizar obras que, en aquella época, eran leídas como tópicos "femeninos", ya por los temas representados, ya por pertenecer a escultoras mujeres.

Empecemos deteniendo la mirada ante un primer grupo: tres autores masculinos, cuyas esculturas fueron distinguidas por el jurado. Comenzando con la obra de Bondone que recibió el primer premio, Comunicación (figura 1), nuestra lectura detecta dos desnudos femeninos que se alejan de la tradición clásica para proponer dos figuras esféricas cercanas a la Venus paleolítica, unas representaciones asociadas con la fertilidad. Su segundo envío, Mujer con espejo (figura 2), proponía una figura similar, pero sosteniendo, en su mano izquierda, un objeto que ha sido recurrente en la historia del arte para señalar una supuesta "vanidad femenina" que condena "moralmente a la mujer cuya desnudez" ha sido representada para el placer masculino (Berger 1980, 59). El material de ambas (terracota) se distancia del "noble" mármol. 


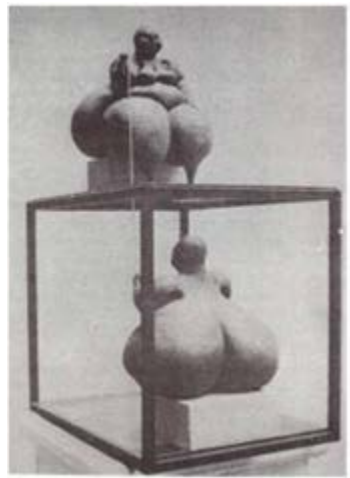

figura 1

Miguel Ángel Bondone, Comunicación terracota. 1er. Premio del SPCC 1982, Córdoba. Colección del MMGP. Estado de conservación: Desconocido (Municipalidad de Córdoba, SPCC 1982, catálogo de exp, p.5).

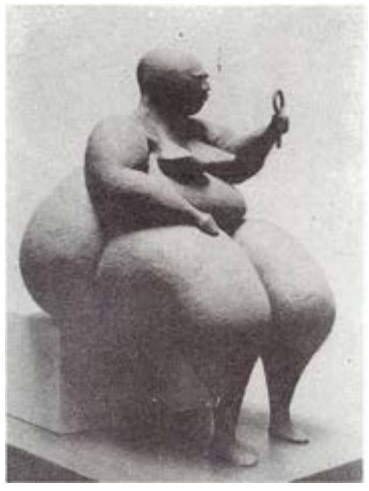

figura 2

Miguel Ángel Bondone, Mujer con espejo, terracota. Estado de conservación: Desconocido (Municipalidad de Córdoba, SPCC 1982, catálogo de exp).

En el trabajo de Zárate, congratulado con el segundo puesto, Éxtasis (figura 3), advertimos el protagonismo de dos antebrazos que se alzan verticalmente que culminan en enérgicos puños cerrados. Relacionando esta pieza con su segundo envío (Guerrero), donde plantea una figura masculina con brazos amputados, consideramos que sus propuestas entraban en diálogo con el contexto de reciente derrota en la guerra de Malvinas, donde en el macrocosmos emergieron cuerpos heridos y deseos de victoria truncados. Sus materiales y técnicas abarcaron chapa batida y hierro soldado.

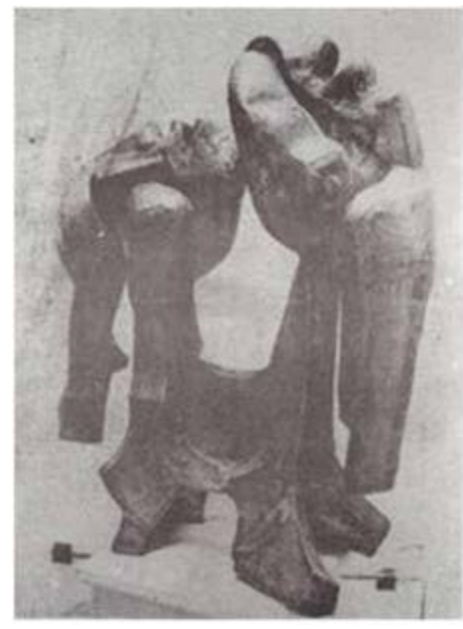

figura 3

Carlos Hipólito Zárate, Éxtasis, chapa batida. $2^{\circ}$

Premio del SPCC 1982, Córdoba. Colección del

MMGP. Estado de conservación: Desconocido

(Municipalidad de Córdoba, SPCC 1982, catálogo de exp, p.7).

Péndulo $V$, de Páez (figura 4), distinguida con la primera mención, presentaba una composición abstracta donde alcanzan a percibirse dos elementos: un cerrojo en la parte inferior y una cadena con una esfera en la parte superior. Esta obra podría leerse, atendiendo al título, como un dispositivo pendular; no obstante, la sensación de movimiento deviene limitada. En su segundo envío (Memorias de una civilización), coincidente con el primero en 
su técnica mixta, la presencia de la cadena se reitera y adquiere protagonismo. Podemos relacionar las estructuras de sentimiento que aquí emergen con el contexto dictatorial del Salón, donde los encadenamientos (de aliados y opositores al régimen) se reacomodaban en aquella coyuntura posbélica.

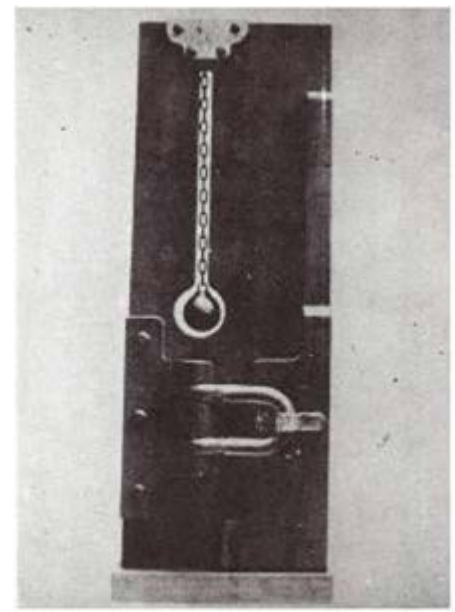

figura 4

Oscar Páez, PénduloV, técnica mixta. $1^{\text {a }}$ Mención del SPCC 1982, Córdoba. Estado de conservación y ubicación actual: desconocidos (Municipalidad de Córdoba, SPCC 1982, catálogo de exp, p.9)

Continuemos el recorrido visual por un segundo grupo: las obras de otros ocho escultores varones que fueron seleccionadas, pero no recibieron premiaciones. Sus creaciones posibilitan transitar en un espectro que abarca desde abstracciones hasta figuraciones. En los trabajos de Kilstein, observamos técnica mixta e imágenes abstractas, aunque sus títulos pueden conducir a reflexiones temáticas. Uno de sus envíos, Tótem (figura 5), remitiría a prácticas metafísicas donde algunos objetos alcanzan funciones sobrenaturales (unas acciones que, desde la lectura oficial de "la civilización occidental y cristiana", eran adjudicadas a culturas "primitivas"). En cuanto a Homenaje a Da Vinci (máquina de volar), podemos pensar en una apropiación, desde corrientes objetuales y cinéticas, de uno de los íconos del Renacimiento. ${ }^{22}$

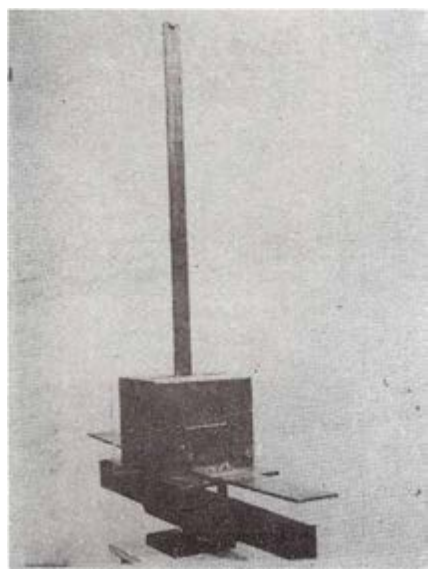

figura 5

Leonardo Kilstein, Tótem, técnica mixta Estado de conservación y ubicación actual: desconocidos. (Municipalidad de Córdoba, SPCC 1982, catálogo de exp, p. 22) 
En la obra de Díaz Navarro, Náyade (figura 6), observamos una discontinuidad: si bien se distancia de los estilos figurativos ofreciendo una forma de contundente abstracción, el nombre del trabajo lo conecta con la canónica cita de temas mitológicos griegos. Esa ninfa de fuentes y manantiales podría interpretarse como una recurrente asociación de lo femenino con la fecundidad. Su segundo envío, también abstracto, se tituló Figura XXXVI, y su material, al igual que el primero, era la madera. Moyano $(2010,195)$ explica:

Su obra no oscila entre grandes cambios, se caracteriza por una búsqueda intuitiva de formas [...] Podemos distinguir un periodo en el cual aliviana los volúmenes y donde lo épico juega un papel activo. Luego regresa al bloque, simplificando formas hasta rayar casi la abstracción [...] La temática constante es la mujer, los hijos y la maternidad.

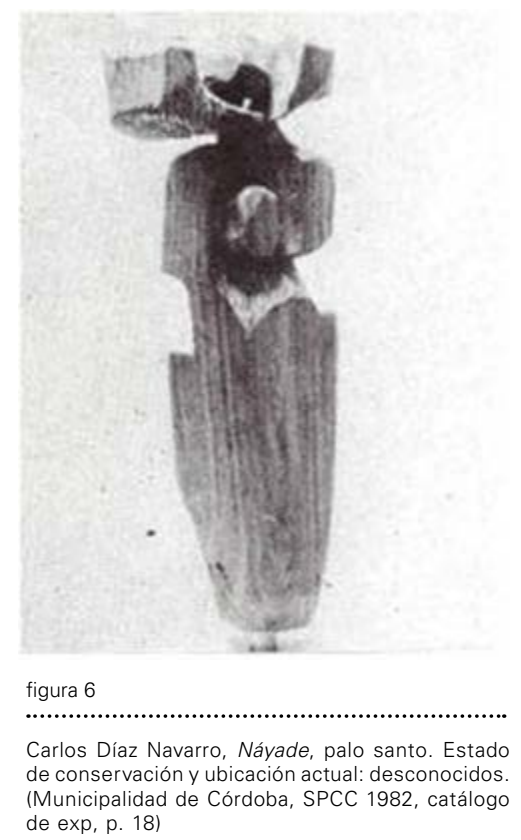

Las obras de Sahade, cuyos materiales y técnicas eran madera y forja, también presentaban abstracciones; es más, podríamos pensar que la supuesta Figura (figura 7) anunciada por los rótulos homónimos de sus dos envíos era una estrategia de competencia para poder entrar en salones oficiales más habituados a aceptar obras representativas que reproducían realidades externas al mundo del arte. Estas, y otras propuestas abstractas que confluyeron en el Salón y Premio Ciudad de Córdoba, entrarían en diálogo con algunas tendencias que, desde el siglo XX, defienden la producción plástica como una tarea experimental que puede inventar nuevas formas y no solo reflejar las ya existentes. En ese marco, no nos parece un dato menor que en otras esculturas de Sahade se reitere el nombre $\operatorname{Sin}$ título. ${ }^{23}$

El Salón también fue prolífico en la selección de obras figurativas. Por ejemplo, la escultura El burgués (figura 8), de Lotz, presentaba un retrato masculino de cuerpo entero: una testa oval con ojos acentuados y un vientre obeso que se alzaba como centro de la composición. Desde una estética mixta, con rasgos realistas y humorísticos, elaboraba una crítica de la burguesía por la acumulación de bienes (no solo) alimenticios. Este discurso podría relacionarse con el marco de aguda crisis económica que estalló en 1981 en Argentina. Su segunda obra, La oceánida, presenta líneas ondulantes, sintéticas y abstractizantes, que conserva como similitud solo la forma de la cabeza. 


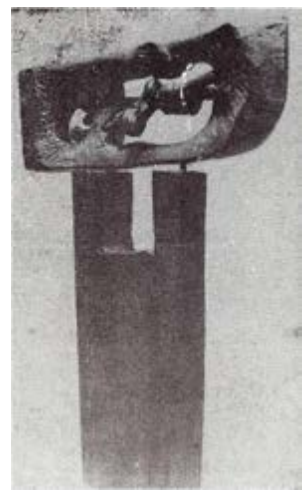

figura 7

Miguel Sahade, Figura, maderay forja. Estado de conservación y ubicación actual: desconocidos. (Municipalidad de Córdoba, SPCC 1982, catálogo de exp, p. 26)

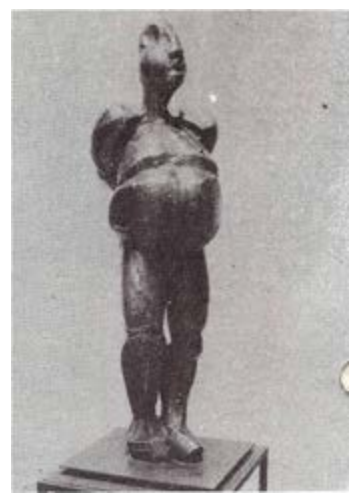

figura 8

Guillermo Lotz, El burgués, hierro Estado de conservación y ubicación actual: desconocidos. (Municipalidad de Córdoba, SPCC 1982, catálogo de exp, p. 23)

En la obra de Criado, Ecuestre // (figura 9), un clásico género de la estatuaria, cuyo tema remitía a la idea de un soldado a caballo, era tensionado en sus dos componentes protagónicos: por un lado, un equino asentado en sus patas derechas poseía sus extremidades izquierdas en parte mutiladas; por otro, la posición de jinete era ocupada por un ser espectral, cuya humanidad no devenía certera. Su segundo envío, Ecuestre I, reiteraba ambas figuras, aunque eran las patas delanteras del caballo las que estaban amputadas. Una posible lectura es asociar estas imágenes con sensaciones de combate y violencia que se multiplicaron durante la guerra de Malvinas.

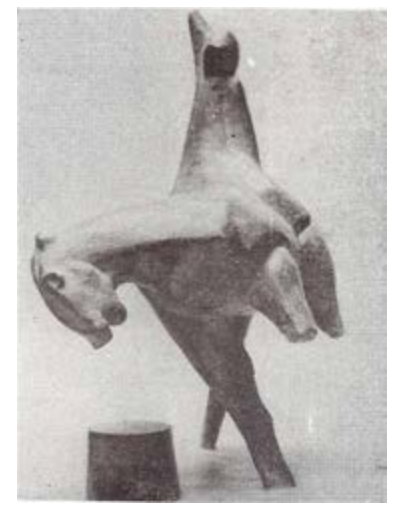

figura 9

Ismael Criado, Ecuestre II, cemento patinado. Estado de conservación y ubicación actual: desconocidos. (Municipalidad de Córdoba, SPCC 1982, catálogo de exp, p. 17)

La representación zoomorfa emergía también en Pájaro fósil, de Álvarez, pero allí la síntesis de la figura adquiría preponderancia. Su segunda obra, Pareja (figura 10), se distanciaba de aquella silueta abstracta y ofrecía un retrato realista, de dos figuras humanas sentadas, cuyas vestimentas y gestos reconstruían una representación androcéntrica tradicionalista: donde un hombre de mayor tamaño, en posición activa, miraba hacia arriba mientras abrazaba a una mujer de contextura más pequeña. Ese binarismo androcéntrico y heterosexista era amplifi- 
cado en otras obras que plasmaban escultóricamente dos estereotipos: mientras "se atribuía a las mujeres debilidad física, intelectual y moral; así como exceso de sentimentalismo", la condición de varón impuso "el control de los sentimientos, la gestión económica", política y científica (Barrancos 2007, 12).

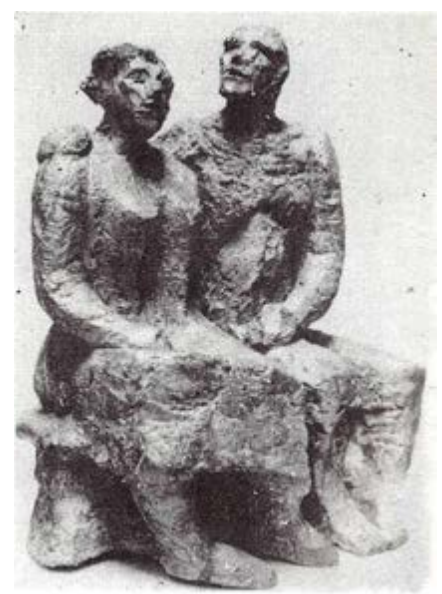

figura 10

Roberto César Álvarez, Pareja, cemento Estado de conservación y ubicación actual: desconocidos. (Municipalidad de Córdoba, SPCC 1982, catálogo de exp, p. 13)

La obra de Garrone Y seréis como dioses. Gn 3:5 (figura 11) proponía un desnudo naturalista de una pareja que recitaba visual y textualmente dos íconos de la Biblia: Adán y Eva. En esta escultura, se combinaban tradiciones estéticas y éticas que asignaban distintos valores a esas figuras. Adán era asociado con el patrimonio de fuerza física e impasibilidad emocional, unas características que se reiteraban en la composición del segundo envío, El lírico, donde Garrone proponía una cabeza masculina en clave neoclásica. En contrapartida, Eva era representada como un cuerpo de menor potencia anatómica, mientras la inclinación de su mirada hacia abajo sugería sumisión y vergüenza ante el pecado material y simbólico que, supuestamente, había originado. ${ }^{24}$

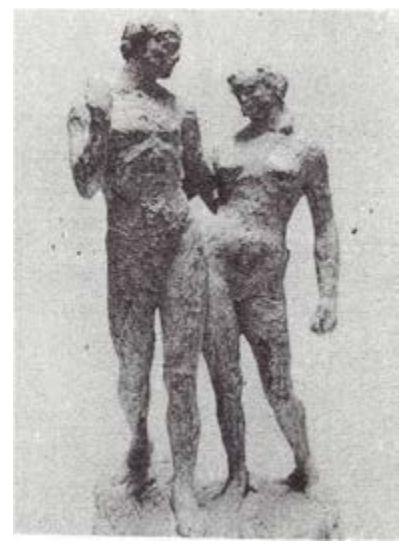

figura 11

Leopoldo Garrone, Y seréis como dioses. Gn 3:5, cemento. Estado de conservación y ubicación actual: desconocidos (Municipalidad de Córdoba, SPCC 1982, catálogo de exp, p. 20) 
Cerrando este segundo grupo, ubicamos las propuestas de Hep. Su Imagen en reposo (figura 12) muestra un objeto de la vida cotidiana: una silla que se metamorfosea en elementos antropomorfos. El lugar del espaldar es ocupado por un torso femenino, decapitado y con brazos truncados, recubierto, parcialmente, con una especie de saco, donde se exhiben senos y ombligo. Oficiando como patas delanteras, emergen dos piernas botas, cuyos pequeños tacos podrían remitir a calzados unisex. Si bien la mixtura de géneros artísticos podría leerse como un rasgo rupturista de los cánones escultóricos, el material elegido (bronce) y el abordaje formal de los fragmentos femeninos la conectan con las tradiciones falocéntricas. El androcentrismo se reitera en su segundo envío: Sensación de costumbre (figura 13). Aquí, mediante chapa batida construyó una mesa con volados asentada sobre patas que presentan dedos con uñas largas esculpidas, objetualización de fragmentos corporales asociados a "lo femenino". Moyano $(2010,263)$ reseña que este agente en 1979 obtuvo la primera mención en el Salón que nos ocupa, "egresa de la Escuela Provincial de Bellas Artes como Profesor de Dibujo y Escultura [y] es discípulo de Horacio Suárez", uno de los agentes que integraba el jurado de 1982.

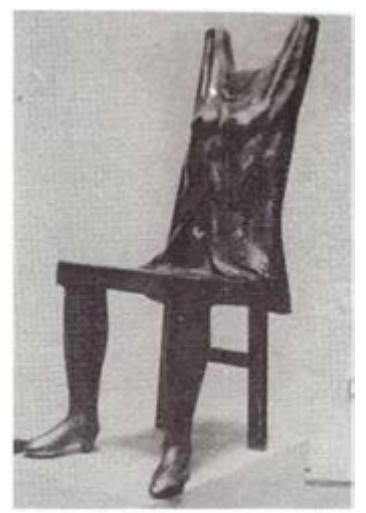

figura 12

Marcelo I. Hepp, Imagen en reposo, bronce batido. Estado de conservación y ubicación actual: desconocidos. (Municipalidad de Córdoba, SPCC 1982, catálogo de exp, p. 21

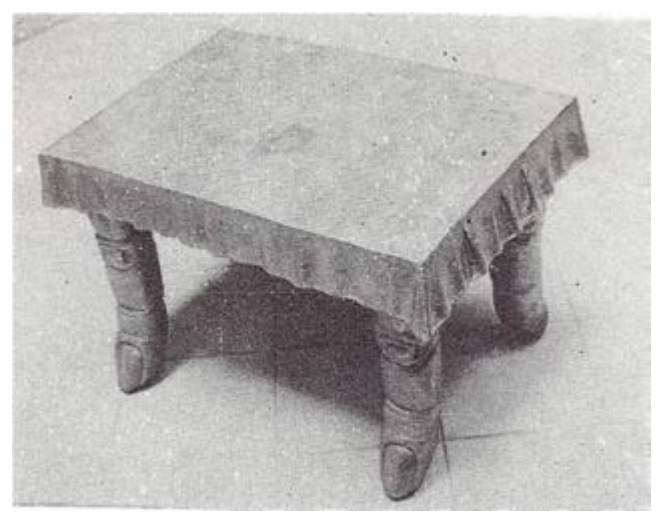

figura 13

Marcelo I. Hepp, Sensación de costumbre, bronce batido. Estado de conservación y ubicación actual: desconocidos. (Municipalidad de Córdoba, SPCC 1982, catálogo de exp, p. 21)

Finalmente, detengamos ante un tercer grupo de imágenes correspondientes al doble envío de las cuatro mujeres, cuyas esculturas fueron seleccionadas para participar del concurso. Una obra de Bersano, El grito (figura 14), fue distinguida en el Salón con una segunda mención. La "opción de compra" para integrar la colección del museo no se habría concretado en este caso, pues dicha pieza permaneció como propiedad de la artista. Su propuesta presentaba un medio torso con elementos desfigurados que se alejaban de la representación realista y se acercaban a un universo simbólico: dos brazos en actitud de plegaria complementados con una cabeza ciclópea que miraba al cielo y una boca abierta de donde parecían emerger alaridos. El título y el tema permiten pensar en reapropiaciones de una clásica pintura de Edvard Munch considerada precursora del expresionismo. Esa resignificación podría sustentarse en dos factores: por un lado, tanto el testimonio de Bersano como el de otros alumnos que cursaron en la Escuela Provincial de Bellas Artes durante la década de 1970 coinciden en afirmar que las vanguardias históricas eran movimientos enseñados en esa academia; por otro lado, ese sonido estridente adquiría ecos en aquel contexto de crisis dictatorial donde los abusos hacia los cuerpos (no solo) "juveniles" ocupaban un lugar protagónico en los medios de comu- 
nicación (Lorenz 2006; alfilo 2016, https://goo.gl/e2k9mB). Su segundo envío, Horizonte (figura 15), tenía el mismo material y técnica que el primero: piedra reconstituida. En torno a la obra general de Bersano, Moyano $(2010,101)$ sintetiza: “Conjuga la sólida formación técnica y una búsqueda conceptual de lo primitivo como medio de expresión, manifestándose a través de medios formales que le permitan plasmar su interés por lo mítico y lo americanista". Respecto de sus trabajos para el Salón de 1982, la escultora recuerda:

[Era] un proceso técnico que resumo: armazón y anclajes de sostén para el modelado, moldes reforzados en yeso. Apertura de moldes, limpieza y carga. Se llama vaciado porque es hueco (Si no sería muuuyyy difícil el traslado). La mezcla lleva piedra molida. De ahí que se llama reconstituida o áridos reconstituidos.

No había un tema específico. Uno enviaba al Salón lo que estaba produciendo en ese momento. El título [...] se va con-formando con la obra. A la distancia, creo que tiene que ver mucho con el inconsciente colectivo de los momentos históricos del país. (Martha Bersano, correo electrónico a la autora, junio de 2017)

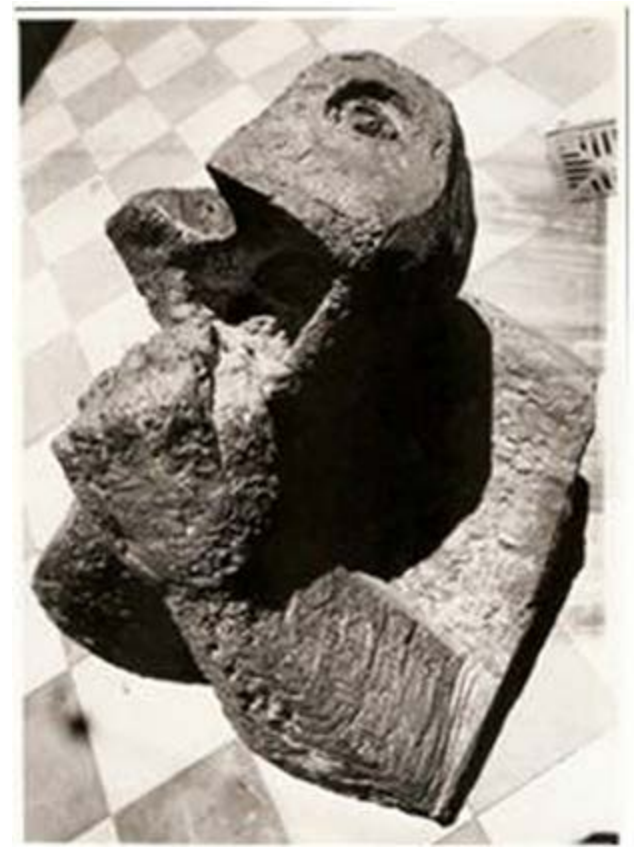

figura 14

Marta Bersano, El grito, piedra reconstituida. $2^{\mathrm{a}}$ Mención del SPCC 1982, Córdoba. Colección de la artista. Estado de conservación existente (Archivo fotográfico de la escultora).

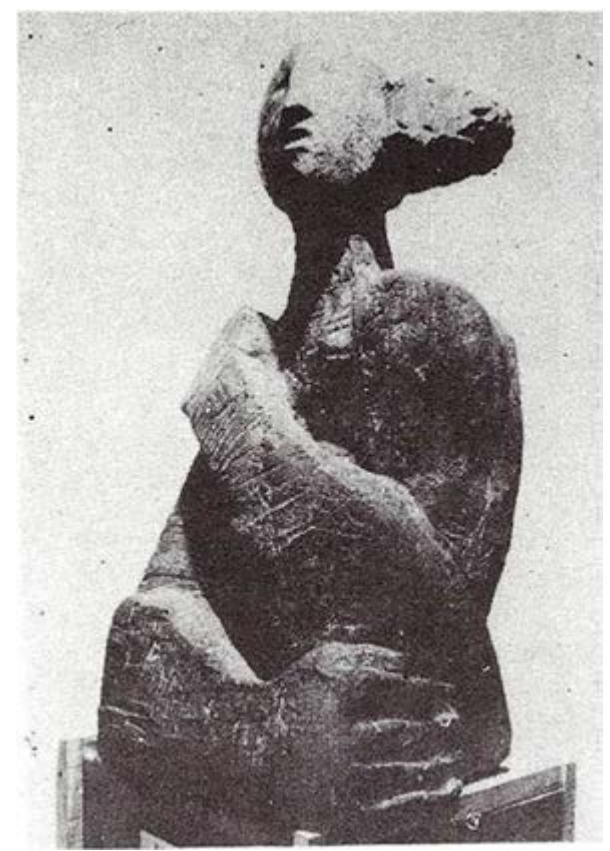

figura 15

Marta Bersano, Horizonte, piedra reconstituida. Estado de conservación: existente. Ubicación actual: Colección de la artista (Municipalidad de Córdoba, SPCC 1982, catálogo de exp, p. 15)

Si la idea de grito podía aludir al contexto epocal de 1982, no parece un dato casual que el tópico de angustia vuelva a irrumpir en una pieza que había sido votada para la segunda mención por tres de los ocho jurados: Vino una paloma que comenzó un tal rumor de lamentos (figura 16), de Raurich-Saba. Si bien la reproducción no permite percibir con nitidez el tema presentado, podemos inferir, según título, que el símbolo internacional de la paz era portador allí de murmullos de llantos o súplicas. Así, se anudaba una coincidencia entre las sensaciones auditivas de dolor propuestas por Martha y Carmen, más allá de las divergencias en cuanto a edades, técnicas y materiales. El segundo envío de Carmen, El día en que los peces soñaran 
ser pájaros (figura 17), compartía las características formales del primero (talla directa en mármol de Carrara), mientras el título reitera el uso de personificaciones y metáforas. Estas obras abstractas del concurso de 1982 se distanciaban de sus producciones de la década de 1950, donde la prensa española la describía como poetiza y escultora figurativa (https://goo.gl/iCbrXJ).

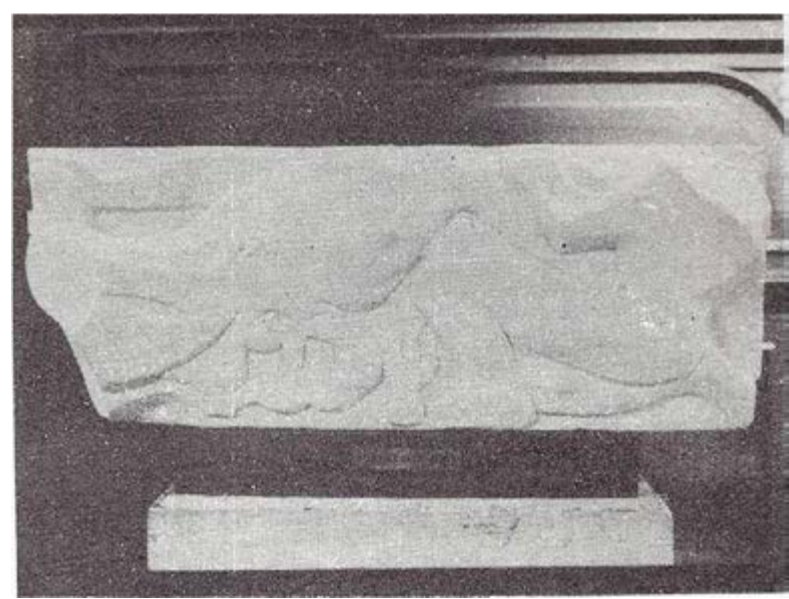

figura 16

Carmen Raurich-Saba, Vino una paloma que comenzó un tal rumor de lamentos, talla directa en mármol. Estado de conservación y ubicación actual: desconocidos (Municipalidad de Córdoba, SPCC 1982, catálogo de exp., p.25).

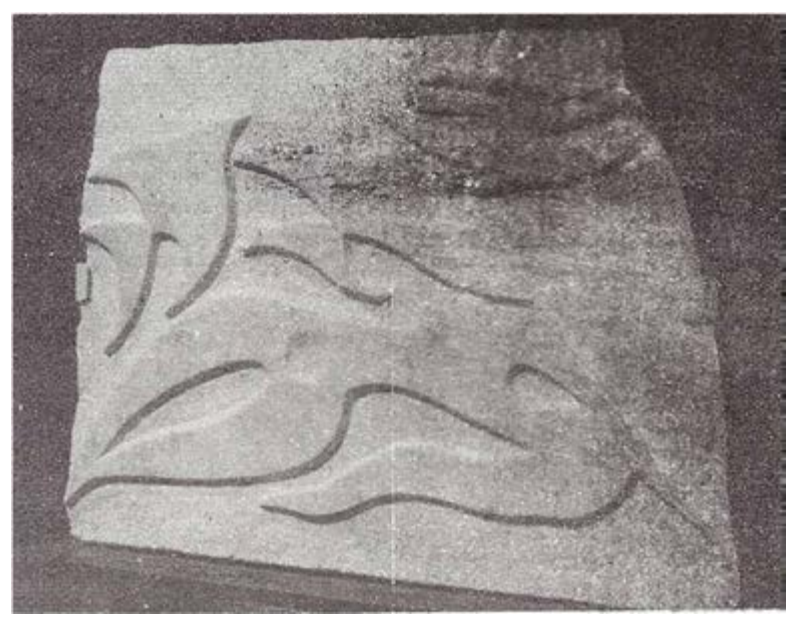

figura 17

Carmen Raurich-Saba, El día en que los peces soñaran ser pájaros, talla directa en mármol. Estado de conservación y ubicación actual: desconocidos (Municipalidad de Córdoba, SPCC 1982, catálogo de exp, p.25

La escultura de Belloni, Intip-Churi (figura 18), ponía en tensión una arista del discurso oficial: si el Salón y Premio Ciudad de Córdoba emergía en el marco de los homenajes por la Fundación de Córdoba (donde el proceso de conquista y colonización era redefinido como una "obra de evangelización"), el título de su obra (que en quechua significaría "hijo del sol') invitaba a pensar en uno de los pueblos arrasados por el Imperio español, los incas. Esta recuperación del pasado latinoamericano mediante lenguajes sintéticos y abstractizantes po- 
dría pensarse como una constante en la producción de Belloni y de otros artistas durante las décadas de 1970 y 1980 (Serviddio 2003). Moyano (2010, 91 y ss.) sitúa una primera etapa de Belloni entre 1981-1990, donde "piedra, bronce y madera, hierro y plomo son los materiales utilizados. Grandes volúmenes representan una figura humana sintetizada y fusionada a la arquitectura, con características de primitivismo megalítico."25

En cuanto a la escultura de Galiasso, Socavón (figura 19), no solo la forma plástica sino también su título plantea disrupciones en relación con las tradiciones escultóricas: aquí el motivo representado concentra nuestras preguntas en torno a lo hueco, quizá, las ausencias. Sobre la obra general de Galiasso, Moyano $(2010,223)$ señala:

Encontramos la presencia de lo antropomórfico, primitivo, totémico y ritual, tanto en los materiales que usa como en la verticalidad preponderante y la estilización de las formas. [...] Tendencia a re-editar el valor de la naturaleza, los mitos, y lo telúrico en el juego de espacios y materias que penetra, perfora y yuxtapone.

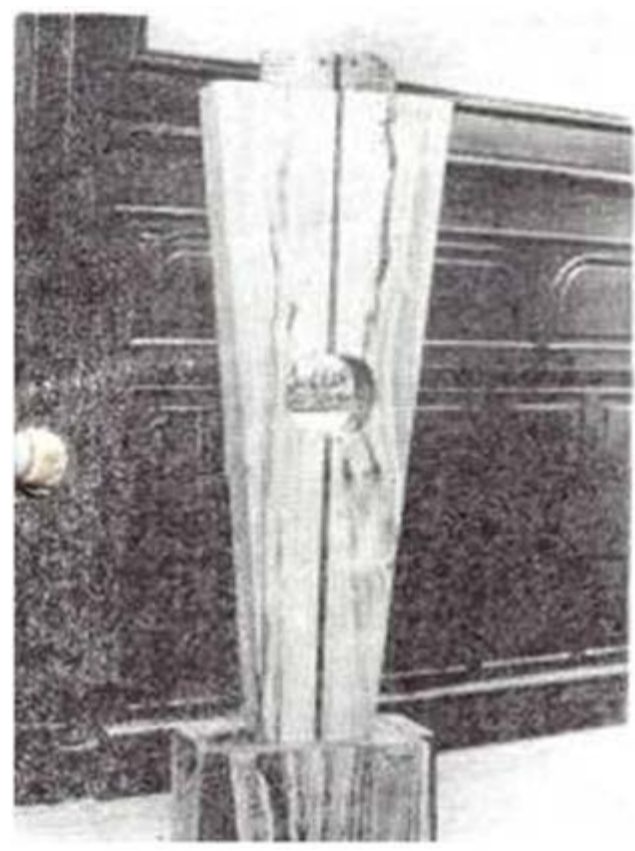

figura 18

María T Belloni, Intip-Churi, ensamble en quebracho. Estado de conservación y ubicación actual: desconocidos. (Municipalidad de Córdoba, SPCC 1982, catálogo de exp, p. 14)

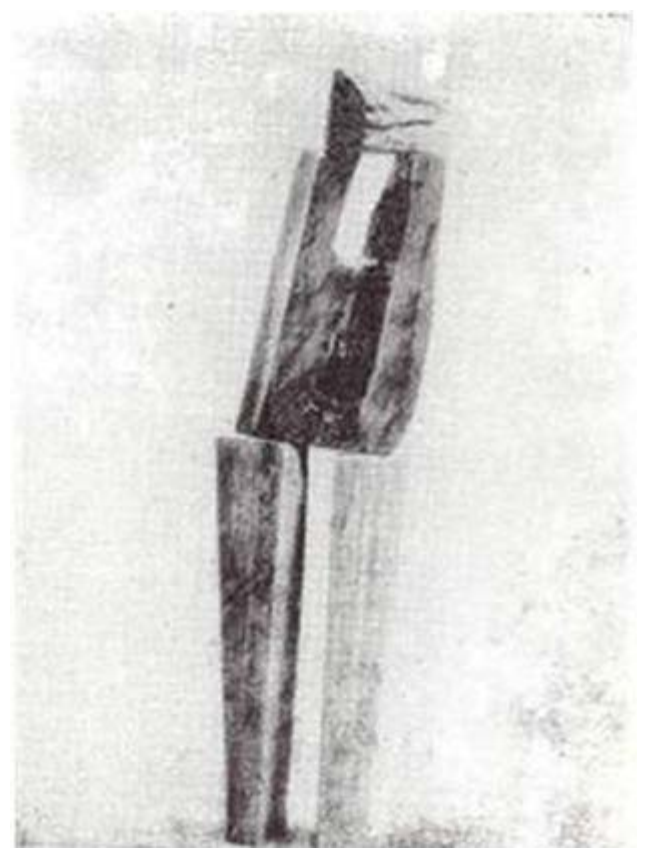

figura 19

Sara Galiasso, Socavón, madera ensamblada. Estado de conservación y ubicación actual: desconocidos. (Municipalidad de Córdoba, SPCC 1982, catálogo de exp, p. 19)

Paralelamente, encontramos puntos de contacto en los segundos envíos de esas dos escultoras: Maternidad y prehistoria, de Belloni (figura 20), y Teresita Batista, de Galiasso (figura 21). Ambas son abordadas desde tendencias abstractas, y a su vez los materiales elegidos se distancian del clasicismo del mármol o del bronce para proponer madera trabajada en técnica de ensamblado. Sobre las temáticas sugeridas por los títulos, podemos pensar que Belloni concretaría una reflexión plástica sobre la función reproductora adjudicada a las mujeres, mientras Galiasso podría aludir al personaje de una novela del brasileño Jorge Amado (Teresa Batista cansada de guerra, 1972), donde se retrataban escenas de violencia sexual. 


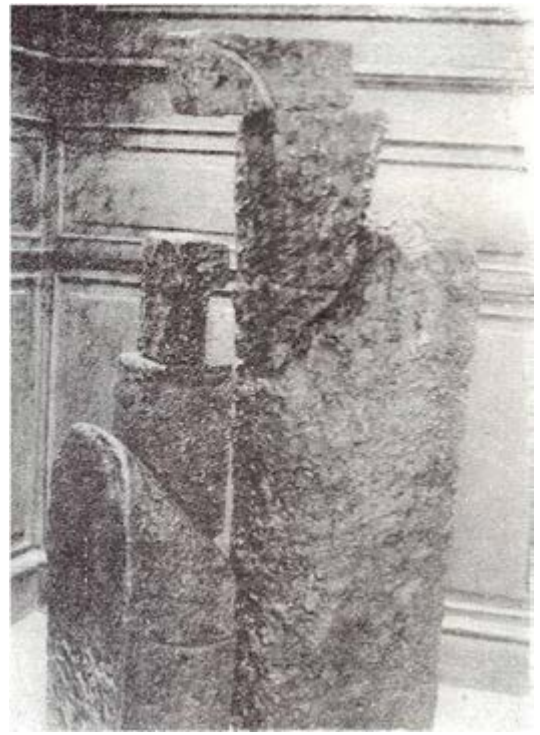

figura 20

María T Belloni, Maternidad y Prehistoria, ensamble en quebracho. Estado de conservación y ubicación actual: desconocidos. (Municipalidad de Córdoba, SPCC 1982, catálogo de exp, p. 14)

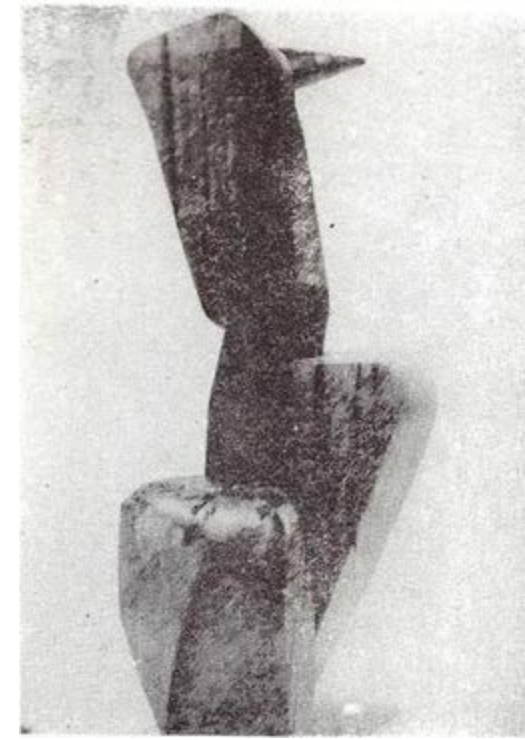

figura 21

Sara Galiasso, Teresita Batista, madera ensamblada. Estado de conservación y ubicación actual: desconocidos. (Municipalidad de Córdoba, SPCC 1982, catálogo de exp, p. 19)

Las propuestas formales de las cuatro escultoras aportaban tensión a una tradición cimentada en la representación mimética, los materiales "nobles" y el androcentrismo. En esas costumbres centenarias del campo artístico occidental, la posición de objeto visual correspondía a la mujer y la de sujeto activo a un creador masculino, quien mediante retratos realistas o naturalistas re-construía una imagen femenina "virtuosa" (anclada en el rol materno) o "pecaminosa" (cuyo cuerpo desnudo era ofrecido a la mirada varonil). Distanciándose de esos mandatos, estas mujeres estaban re-afirmando su posición de artistas mediante la producción de esculturas donde, en lo plástico, prevalecían las propuestas abstractas, mientras sus títulos transitaban un espectro complejo de problemáticas: desde vivencias corporales "femeninas" como la maternidad hasta tematizaciones poético-políticas de un contexto social donde se reinventaban los lazos trans-locales de Córdoba con las culturas prehispánicas, mientras se escuchaban gritos y lamentos.

\section{A modo de cierre y apertura}

Sinteticemos algunos avances y nuevas lagunas emergentes en torno a la tarea de reconstruir una historia sobre la presencia de las mujeres en las artes plásticas de Córdoba durante la última dictadura argentina. El Salón y Premio Ciudad de Córdoba, patrocinado desde el Gobierno, devino un objeto empírico fructífero para conocer algunas prácticas de ese campo del arte que entablaba redes culturales y políticas en el contexto local, nacional e hispanoamericano. Si bien "el análisis cultural es intrínsecamente incompleto", el arribo a una comprensión parcial (Geertz 2003; Haraway 1995) se complejiza aún más si tenemos en cuenta que las huellas documentales sobre ese concurso museográfico de las décadas de 1970 y 1980 no están resguardadas en un único archivo o museo, sino que se encuentran dispersas y solo perviven algunos fragmentos. 
El análisis cuantitativo de seis de los siete catálogos correspondientes a las ediciones anuales del Salón desarrolladas entre 1977 y 1983 permitió detectar una escasa presencia femenina en las posiciones de jurado o artista. En general, dentro de un jurado compuesto por nueve miembros, la participación femenina se restringió a un integrante (11 \%), excepto en dos casos: mientras en la primera edición no se convocó a ninguna mujer, en la segunda se invitó a tres. A la par, dentro del conjunto de los artistas, cuyas obras habían sido aceptadas para concursar, se mantuvo una minoritaria visibilidad femenina, aunque hubo variaciones e incrementos en cada disciplina: en las ediciones dedicadas a pintura, encontramos desde 11 a $21 \%$, en los concursos de dibujo detectamos un aumento de 12 a $21 \%$, mientras en las competencias de grabado hallamos un crecimiento de 37 a 50 \%. En cuanto al Salón de Escultura, no disponemos de datos sobre la edición de 1979; pero el catálogo de 1982 evidencia 26.6 \% de mujeres artistas. Las futuras investigaciones podrán decir si esas cifras diferenciales del Salón guardaban relación con la cantidad de ingresantes y egresadas en las distintas especialidades plásticas que podían transitarse en aquel contexto como estudios superiores.

Las cifras de las presencias femeninas disminuían aún más entre los autores, cuyas obras recibían distinciones. De manera habitual, el Salón asignaba dos premios adquisición y dos menciones con opción a compra; esporádicamente, también asignaba menciones honoríficas. La distinción de obras de artistas mujeres recayó con frecuencia en la segunda mención, es decir, en el cuarto y último lugar. Esas prácticas tuvieron particulares consecuencias materiales y simbólicas. Por un lado, implicó efectos inmediatos en la reproducción socioeconómica de los artistas: los recursos monetarios asignados por el Salón variaban, de mayor a menor monto, según se obtuviera el primer puesto en los premios o el cuarto lugar en las menciones. Por otro lado, involucró consecuencias a largo plazo en la conformación de la colección estable del Museo Municipal de Bellas Artes Dr. Genaro Pérez: las únicas obras que tenían posibilidad certera de pasar a integrar ese patrimonio eran aquellas distinguidas con el primer y segundo premio. Esto se tradujo tanto en una conservación de piezas de autores masculinos como en un olvido e invisibilización de las escasísimas obras de autoras femeninas que habían sido compradas opcionalmente y a bajo costo.

Cualitativamente, profundizamos en el análisis del salón escultórico de 1982. Su inauguración, a la cual asistieron autoridades como el gobernador, se dio en el marco de las performances por el aniversario fundacional hispánico de Córdoba, aunque el clima festivo habitual estuvo eclipsado por el contexto de derrota en la guerra de Malvinas. En cuanto a los artistas aceptados y premiados, detectamos una pirámide jerárquica que distinguía artistas jóvenes en la base, artistas reconocidos en una posición intermedia y artistas consagrados en la cúspide. En esos escalones, se combinaban clasificaciones etarias y genéricas: mientras la base se caracterizaba por una composición pluralista de jóvenes y adultos, hombres y mujeres, en la posición intermedia y en la cúspide, las condiciones de acceso y permanencia estaban reservadas para los productores mayores y masculinos. El androcentrismo del campo quedaba evidenciado en una práctica singular: mientras una obra de un autor autodidacta (que representaba a un cuerpo femenino desnudo) era distinguida con el primer premio, las esculturas de una egresada con doble titulación académica no recibieron ni siquiera una mención. Queda pendiente profundizar en los condicionantes de clase social y sus interacciones con las variables genéricas y generacionales. El factor socioeconómico adquiriría un papel especial para la escultura, pues, como argumentaba la prensa de la época, era una actividad "costosa y relegada de los salones locales." 
Respecto de las esculturas, el catálogo ofrecía, excepcionalmente, la reproducción de las treinta obras aceptadas. Ante esas imágenes, se propusieron dos recorridos entrelazados: por una parte, ensayar interpretaciones personales frente a piezas figurativas y abstractas; por otra parte, explorar si "lo femenino" emergía, no solo como el clásico objeto visual-sensual producido por y para hombres, sino como espacio de agencia para las escultoras mujeres. Retuvo nuestra atención un grupo de obras donde prevalecía la figuración (aunque podían encontrarse rasgos abstractizantes), las cuales dialogaban con las estructuras de sentimiento de aquella coyuntura dictatorial posguerra de Malvinas y cuyas temáticas traspasaban a distintas generaciones y géneros de creadores: una estatua de un Guerrero mutilado, un retrato Ecuestre donde el jinete era una figura espectral y el caballo tenía sus patas amputadas, una figura ciclópea con una acentuada boca que proponía un Grito y una pieza cuyo título aludía a Rumores de lamentos. Paralelamente, un conjunto de obras abstractas, entre cuyos autores predominaban jóvenes artistas, tanto hombres como mujeres, nos condujeron a reflexionar sobre la posible existencia de una postura crítica hacia la función representacional asignada, tradicionalmente, a las artes plásticas.

Restan de investigar varias huellas, fantasmas y olvidos, para poder escribir una historia de la escultura (de sus poéticas y políticas, materiales y técnicas) donde se visibilicen los condicionantes de género que hicieron posible la presencia y la ausencia de las mujeres en la sociedad cordobesa y argentina de los años dictatoriales. Las fuentes sobre aquella coyuntura muestran la pervivencia de una generación de escultoras nacidas en las décadas de 1910 (Clara Ferrer Serrano) y 1920 (Carmen Raurich-Saba). Sin embargo, esos documentos son escasos (y casi inexistentes para los casos de Marta Giraudo y Mora Flores) situación que complejiza la tarea de una reconstrucción histórica, en la cual se pueda dar cuenta de las trayectorias biográficas y académicas que hicieron posible, para algunas mujeres, disputar una tradición plástica reservada, especialmente, para la supuesta "fuerza masculina".26 Conjuntamente, tres escultoras participantes del Salón y Premio Ciudad de Córdoba (Teresa Belloni, Martha Bersano y Sara Galiasso) eran calificadas a inicios de la década de 1980 como jóvenes artistas, mientras la historia del arte reciente (Moyano 2010) las asocia estéticamente con "primitivismo y americanismo". Aquí se abre un eje de problemáticas que ameritan ser indagadas en otros trabajos: las posibles apropiaciones de "lo precolombino como herramienta del discurso latinoamericano en los años setenta" y ochenta (Serviddio 2003).

\section{NOTAS}

1. Agradezco al Dr. Federico Alvez Cavannapor su colaboración en la traducción al portugués del resumen de este artículo.

2. Quiroga (2004) diferencia cuatro fases dentro de la última dictadura argentina: 1) Legitimación (1976-mediados de 1978). 2) Deslegitimación (1978-1979). 3) Agotamiento, 1980-1982. La crisis comenzada en 1980 (cuando se precipitan las tensiones sociales acumuladas en años precedentes y se vislumbra la vulnerabilidad del sistema financiero) irá acrecentándose. Así, se desemboca en la siguiente fase: 4) Descomposición (mediados de 1982-finales de 1983). Derrumbe por disidencias internas en las Fuerzas Armadas, derrota en la guerra de Malvinas (que agudiza esas diferencias) y crisis económica. Sobre los alcances de la dictadura argentina en (y desde) Córdoba, puede consultarse Revista Alfilo (2016). 
3. En las fiestas oficiales por el Día de la Juventud, el Estudiante y la Primavera, celebradas durante la última dictadura, encontramos una práctica recurrente de división de sexo-género en el ámbito local y nacional: la elección de la reina. Esta competencia de capitales corporales y bienes simbólicos "nobiliarios" era la principal visibilidad asignada por el Gobierno a las jóvenes, quienes emergían como objetos estéticos, cuya primordial función recaía en decorar algunas vidas masculinas, las de "los jóvenes heroicos". Mientras el discurso gubernativo presentaba como requisito del concurso la posesión de un recurso cultural (ser estudiantes del secundario), la selección de la consagrada no se dirimía con evaluaciones cognitivas, sino con concursos de belleza, premiación que estaría condicionada por la correspondencia anatómica y étnica con el canon imperante (González 2014b).

4. Córdoba fue fundada en el siglo XVI por colonizadores españoles, siendo reconocida en la vigésima centuria por su desarrollo industrial y cultural. Es llamada "la Docta" en alusión a que su universidad, creada en 1613, es la más antigua del país y la cuarta de América. También se la denomina Ciudad de las campanas en referencia a las múltiples iglesias católicas que emergen en su suelo. Junto con esas representaciones tradicionalistas, a lo largo del siglo XX dos acontecimientos le dieron reconocimiento inter-nacional como revolucionaria: la Reforma Universitaria de 1918 y el levantamiento obrero-estudiantil conocido como el Cordobazo (1969). La efervescente actividad político-cultural entre finales de la década de 1960 y comienzos de la década de 1970 difundieron el calificativo de combativa. Así, esta ciudad fue uno de los espacios clave de implantación de la última dictadura. Según el Censo Nacional de 1980, la población provincial ascendía a 2407754 que la ubicó en tercer lugar después de Buenos Aires y Santa Fe.

5. Otro de los focos de atención fueron los jóvenes. En relación con las juventudes in-visibilizadas en aquella coyuntura, se corroboró otra hipótesis: las biopolíticas juveniles aplicadas en la última dictadura se sustentaban en una mentalidad autoritaria, en un imaginario bélico y en un modelo civilizatorio militarista. Desde esa matriz ideológica, la población joven fue dividida, en las representaciones, en tres grandes grupos: enemigos-subversivos, heroicos-virtuosos e indiferentesdesorientados. Esas imágenes culturales condicionaron distintas estrategias de domesticación que comprendieron desde la vigilancia y el exterminio hasta múltiples y variadas políticas culturales (González 2014a).

6. En las fiestas oficiales por el Día de Córdoba también se producían performances musicales (conciertos de música clásica) y teatrales (donde se representaba el acto fundacional) (González 2014b).

7. Al cotejar la carrera de los artistas contemporáneos, según la división genérica, Méndez (1995) observa que los ámbitos profesionales exitosos aparecen monopolizados por los hombres, aunque la mayoría de las egresadas en las academias sean mujeres. Para el campo artístico de Buenos Aires, pueden consultarse las investigaciones de Rosa $(2008,2009)$.

8. Pintores: Ahumada, Alberti, Amici, Angelelli, Bastos, Berra, Bonome, Canedo, Carranza, Cárrega Núñez, Criado, Churquina, Della Puppa, Di Rienzo, Durieux, Fonseca, Fraticelli, Gastaldi, Gubiani, Gutnisky, Guzmán, Herrera, Leone, López, Miravet, Monteiro, Negrni, Oliva, Olivan, Olocco, Ortiz, Rojas, Scieppaquercia, Sosa Luna, Videla.

9. Dibujantes masculinos: Alberti, Bearzotti, Berra, Carranza, Cárrega Núñez, Criado, Durieux, Fonseca, Herrera, Leone, Monteiro, Murúa, Negrni, Ortiz, Peiteado, Pecker, Pinto, Rojas, Saavedra, Salas, Scieppaquercia. Grabadores: Crespín, Galetto, Rojas, Sica, Tejeda.

10.Pintores: Basaldúa, Bonome, Bruno Lasalle, Canedo, Calafell, Cárrega Núñez, Cárrega O'Dena, Castello, Cerrito, Crespo, Curtino, Churquina, Del Prato, Di Rienzo, Fonseca, Guerreiro, Guggia, Herrera, Leone, Medina, Miravet, Monteiro, Molina Rosa, Oliva, Olocco, Rojas, Silva, Simpson, Scieppaquercia, Sosa Luna, Videla.

11.Dibujantes masculinos: Alberti, Amuchástegui, Canedo, Carranza, Chuljak, Da Porta, Echevarrieta, Fraticelli, Grinberg, Hepp, Herrera, Leone, Menas, Moreno Villafuerte, Ojeda, Pinto, Rojas, Scieppaquercia, Sosa Luna. Grabadores: Bastos, Geri, Décima, Galetto, Rojas, Simes.

12.Pintores: Bernasconi Castellano, Canedo, Carrega Núñez, Córdoba, Crespo, Cándido Churquina, Daniel Delprato, Fraticelli, Luis Galán Núñez, Gómez, Grinberg, Ledda, Mantegani, Martínez, Menas, Olocco, Pino, Roldán, Rojas, Scieppaquercia, Seguí, Sosa Luna, Videla. 
13. Notas biográficas sobre ellas pueden encontrarse en la web de la Academia Nacional de Bellas Artes y en un video documental publicado por dicha entidad en 2013 (https://goo.gl/NQU2nt y https://goo.gl/JE5Nqh).

14. El proyecto de que la exhibición del Salón y Premio Ciudad de Córdoba deviniera muestra itinerante, ya estaba presente en los objetivos de 1977, aunque los destinos planificados eran otras provincias.

15.Las futuras investigaciones podrán explicar el proceso de institucionalización que llevó a la existencia de este Museo de las Mujeres. Dependiente del Gobierno de Córdoba, fue inaugurado en 2011 y reabierto en marzo de 2017, luego de estar cerrado por remodelaciones durante un año (Gobierno de la Provincia de Córdoba 2017).

16.Si bien Zárate era de procedencia riojana, se domiciliaba en Córdoba, al menos, desde 1980, ya que uno de los requisitos del Salón y Premio Ciudad de Córdoba era de una antigüedad mínima de dos años de residencia.

17. Una página educativa de 2001 lo clasifica como artesano y artista: "Miguel Bondone es artesano. Su tiempo, es el tiempo de un hombre de 62 años que, ya jubilado, pasa sin apuros la mitad del año en Los Hornillos y la otra mitad en Bell Ville [...] Cierto es aquello que dice que quien trabaja con sus manos es un trabajador manual, el que lo hace con sus manos y su cabeza es un artesano, pero el que trabaja con manos, cabeza y corazón es un artista" (Escuelas.edu.ar 2012).

18.Catálogo de la muestra Arte Joven, 1982, Córdoba, Museo Provincial de Bellas Artes Emilio Caraffa.

19.Su reconocimiento en España y en la capital federal podría explicar que tres miembros del jurado se inclinaran por la distinción de una de sus obras en 1982 "Buenos Aires. Notas porteñas (crónica por correo aéreo). Expone en galerías Peusser 22 obras suyas [...] Carmen Raurich se trasladó a la Argentina hace tres años e instaló su estudio en la apartada y docta ciudad de Córdoba [...] continúa una obra anterior ya elogiada en Barcelona" (La vanguardia española, 30 de noviembre de 1958, https://goo.gl/P2miPj)

20. Una noticia de 2010 ( La Voz del Interior) ubica a Álvarez, Lotz y Solís formando parte de "Muestra de esculturas colectivas" (https://goo.gl/GP4jKN).

21.Las reproducciones eran en blanco y negro, mientras la información textual era escasa: nombres del artista y de la obra junto a mínimos datos sobre materiales y, en algunos casos, técnicas.

22. Beltramini Zubiri (2011) muestra que Kilstein era calificado como artista, pero también como artesano.

23.En una retrospectiva de 2006 sobre sus esculturas, se expusieron 47 piezas donde predominaban los motivos abstractos. En ese conjunto, 11 trabajos estaban rotulados con la indicación Sin título (Catálogo, Miguel Carlos Sahade, Sala de Exposiciones Ernesto Farina, Córdoba, 2006). Un texto de Martha Bersano (2006, 37 y ss.), incluido en ese catálogo, aportaba un análisis plástico de la obra general de Sahade.

24. Moyano $(2010,232)$ informa que este agente había nacido en 1916 y había egresado de la Escuela Provincial de Bellas Artes en 1946: "escultor [... ] con neta influencia clásica".

25.Usubiaga $(2002,157)$ afirma que, ya desde la década de 1970, algunos creadores de Buenos Aires se inclinaron por "la recuperación de la imaginería indígena latinoamericana dentro del lenguaje abstracto".

26.Sobre esas cuatro mujeres, Moyano (2010) solo registra a Ferrer Serrano.

\section{REFERENCIAS}

Academia Nacional de Bellas Artes. 2017. "Nelly Kirger de Perazzo," acceso el 5 de mayo de 2017, https://www.youtube.com/watch?v=pylf2-GY1tA

Barrancos, Dora. 2007. Mujeres en la sociedad argentina: una historia de cinco siglos. Buenos Aires: Sudamericana.

Beltramini Zubiri, Alicia Estela. 2011. “Leonardo Kilstein: una celebración de los materiales". Arte. http:// www.arte-online.net/Notas/Leonardo_Kilstein._Una_celebracion_de_los_materiales 
Berger, John. 1980. Modos de ver. Barcelona: Gustavo Gilli.

Bersano, Martha. 2006. "Miguel Carlos Sahade, una trayectoria abierta". Catálogo de muestra: Miguel Carlos Sahade, Sala de Exposiciones Ernesto Farina, Córdoba.

Blázquez, Gustavo. 2007. “El arte de contar la historia: una lectura de la producción historiográfica sobre arte contemporáneo en Córdoba." Presentación en IV Congreso Internacional de Teoría e Historia de las Artes: Imágenes perdidas: censura, olvido, descuido, Asociación Amigos del Museo Nacional de Bellas Artes, Buenos Aires, septiembre 25-29.

Bourdieu, Pierre. 2000. La dominación masculina. Barcelona: Anagrama.

— 2002. "La juventud no es más que una palabra". En Sociología y cultura, 163-173. México: Grijalbo.

- 2003. Creencia artística y bienes simbólicos. Buenos Aires: Aurelia Rivera.

Butler, Judith. 1999. "Sujetos de sexo, género, deseo." En Feminismos literarios, compilado por Neus Carbonell y Meri Torras, 3-43. Madrid: Arco Libros.

Centro Virtual de Arte Argentino. 2017. “Lola Mora”, acceso el 16 de junio de 2017, http://cvaa.com. ar/03biografias/mora_lola.php

De Diego, Estrella. 1999. "Figuras de la diferencia." En Historia de las ideas estéticas y de las teorías artísticas contemporáneas, editado por Bozal Valeriano, 434-451. Madrid: La balsa de la Medusa.

Didi-Huberman, Georges. 2008. Ante el tiempo: historia del arte y anacronismo de las imágenes. Buenos Aires: Adriana Hidalgo.

Escuelas.edu.ar. 2012. "Miguel Ángel Bondone", acceso el 17 de enero de 2012, http://www.oni. escuelas.edu.ar/2001/cordoba/bellville/cult/bondone.htm

Escuela Superior de Bellas Artes Fernando Fader. 2017. “Historia del Instituto," acceso el 16 de mayo de 2017, http://isfader.cba.infd.edu.ar/sitio/index.cgi?wid_seccion=1\&wid_item=9

Foucault, Michel. 1992. Microfísica del poder. Madrid: La Piqueta.

Fundación Konex. 2017. "Premios Konex - 1982 - Artes Visuales". acceso el 15 de marzo de 2017, http://www.fundacionkonex.org/premios1982-artes-visuales

Geertz, Clifford. 2003. La interpretación de las culturas. Barcelona: Gedisa.

Ginzburg, Carlo. 2006. El hilo y las huellas: lo verdadero, lo falso, lo ficticio. Traducido por Luciano Padilla López. Buenos Aires: Fondo de Cultura Económica.

Gobierno de la Provincia de Córdoba. 2017. “Vuelve a abrir sus puertas el Espacio Cultural Museo de las Mujeres", acceso el 14 de marzo de 2017, http://prensa.cba.gov.ar/cultura-y-espectaculos/ renovado-el-momu-vuelve-abrir-sus-puertas/

González, Alejandra Soledad. 2014a. "Una fiesta oficial en la última dictadura argentina: la Semana de la Juventud en 1982". En Juventudes, políticas culturales y prácticas artísticas, coordinado por Alejandra Soledad González y María Verónica Basile, 61-86. Córdoba: Alción.

— 2014b. "Políticas culturales en la última dictadura argentina (1976-1983): fiestas oficiales, reinvención de tradiciones hispánicas e intersticios de resistencia artística". ArtCultura: Revista de História, Cultura e Arte 16 (28): 143-160. http://www.seer.ufu.br/index.php/artcultura/article/view/30614

Haraway, Donna. 1995. Ciencia, cyborgs y mujeres: la reinvención de la naturaleza. Traducido por Manuel Talens. Madrid: Cátedra.

Herrera, Ángel y Menas, Rubén. Entrevista pública y colectiva realizada por A. Soledad González, Córdoba 6 de junio de 2017. Mesa de Diálogo sobre Dibujo producida por A.S. González y Sara Picconi. Universidad Provincial de Córdoba.

Invernizzi, Hernán y Judith Gociol. 2002. Un golpe a los libros: represión a la cultura durante la última dictadura militar. Buenos Aires: Eudeba.

La Vanguardia Española. 1958. "Notas porteñas", 30 de noviembre. http://hemeroteca.lavanguardia. com/preview/1958/11/30/pagina-19/32761739/pdf.html

LaVoz. 2010. "Muestra de esculturas colectivas", acceso el 11 de diciembre de 2010, http://vos.lavoz. com.ar/node/292042 
Levi, Giovanni y Jean-Claude Schmitt, comps. 1996. Historia de los jóvenes. Madrid: Taurus.

Lorenz, Federico Guillermo. 2006. Las guerras por Malvinas. Buenos Aires: Edhasa.

Méndez, Lourdes. 1995. Antropología de la producción artística. Madrid: Síntesis.

Miller, Toby y Geroge Yúdice. 2004. Política cultural. Barcelona: Gedisa.

Moyano, Dolores, dir. 2010. Diccionario de artistas plásticos de Córdoba: siglos XX y XXI. Córdoba: Imprenta de la Lotería de Córdoba.

Myers, Jorge. 2002. "Historia cultural." En Términos críticos de sociología de la cultura, compilado por Carlos Altamirano, 126-128. Buenos Aires: Paidós.

Museo Caraffa. 2017. "Museo Caraffa - 100 años", acceso el 13 de marzo de 2017, http://www. museocaraffa.org.ar/blogcentenario/?cat=5

Pollock, Griselda. 1991. “Mujeres ausentes (Un replanteamiento de antiguas reflexiones sobre imágenes de la mujer)." Revista de Occidente 127: 7-107.

Postay, Viviana. 2004. Los saberes para educar al soberano, 1976-1989. Córdoba: Ferreyra.

Quiroga, Hugo. 2004. El tiempo del "Proceso": conflictos y coincidencias entre políticos y militares. Rosario: Fundación Ross.

Revista Alfilo - Facultad de Filosofía y Humanidades Universidad Nacional de Córdoba. 2016. “Especial alfilo. 40 aniversario del Golpe Cívico-Militar de 1976", acceso el 1 de mayo de 2016, https://ffyh. unc.edu.ar/especial-24marzo/

Rosa, María Laura. 2008. “La cuestión del género". En Cuestiones de arte contemporáneo, editado por Elena Oliveras, 153-174. Buenos Aires: Emecé.

- 2009. “Las/los invisibles a debate." En Género y sexualidades en las tramas del saber, coordinado por Solvia Elizalde, Karina Felitti y Graciela Queirolo, 97-128. Buenos Aires: libros del Zorzal.

Schechner, Richard. 2000. Performance: teoría y prácticas interculturales. Buenos Aires: Libros del Rojas.

Serviddio, Fabiana. 2003. "Ser latinoamericano: lo precolombino como herramienta del discurso latinoamericano en los años setenta". En Poderes de la imagen, 1-11. Buenos Aires: Centro Argentino de Investigadores de Arte.

Tatarkiewicz, Wladislaw. 2002. Historia de seis ideas: arte, belleza, forma, creatividad, mimesis, experiencia estética. Madrid: Tecnos.

Usubiaga, Viviana. 2012. Imágenes inestables: artes visuales, dictadura y democracia en Buenos Aires. Buenos Aires: Edhasa.

Williams, Raymond. 2000. Marxismo y literatura. 1977. Barcelona: Península.

\section{Cómo citar este artículo:}

González, Alejandra Soledad. 2018. “Artes plásticas y mujeres en la última dictadura argentina: análisis desde un caso trans-local." Cuadernos de Música, Artes Visuales y Artes Escénicas 13 (1):13-42. doi:10.11144/javeriana.mavae13-1.apmu 